\title{
Boris Krajnc in drugi kemiki na dachauskih procesih
}

\author{
Marko Dolinar \\ Univerza v Ljubljani, Fakulteta za kemijo in kemijsko tehnologijo, Katedra za biokemijo, \\ Večna pot 113, 1000 Ljubljana, Slovenija \\ *Corresponding author: E-mail: marko.dolinar@fkkt.uni-lj.si
}

Received: 06-03-2021

\section{Povzetek}

Boris Krajnc je bil prvi habilitirani učitelj ljubljanske univerze za področje biokemije - imenovanje v naziv docenta je datirano s 5. januarjem 1946. Vendar se je Krajnčeva življenjska pot zelo hitro končala, saj so ga 27. oktobra 1947 aretirali in 26. aprila 1948 na montiranem dachauskem procesu obsodili na smrt. Ustrelili naj bi ga 12. maja 1948, starega 34 let. Krajnčeva življenjska zgodba je tesno povezana z delom več slovenskih kemikov, ki so bili kot zaporniki v koncentracijskem taborišču Dachau izbrani za tehnično pomoč pri izvedbah poskusov na ljudeh ali pri delu v kliničnem laboratoriju. Na povojnih dachauskih procesih v Ljubljani je bilo skupaj obsojenih 8 kemikov, od teh jih je bilo 5 obsojenih na smrt in ustreljenih. V kasnejših presojah dachauskih procesov se je izkazalo, da so bile obtožnice skonstruirane, priznanja pa pridobljena s krutimi zasliševalskimi metodami, zato so bile vse sodbe razveljavljene. Po emigraciji encimatika Richarda Klemna ter pregonu Maksa Samca in Marte Blinc z univerze je bil Boris Krajnc tisti, ki naj bi skrbel za biokemijo na Tehniški fakulteti. Po njegovi smrti je nekaj let biokemijo predaval Krajnčev mlajši kolega Dušan Stucin z Medicinske fakultete, potem pa biokemije več let ni bilo v kemijskem kurikulumu.

Ključne besede: biokemija; dachauski procesi; Polygal; strjevanje krvi

\section{Uvod}

Dachauski procesi je skupno ime za politične procese v letih 1948 in 1949, v katerih je bilo skupaj obsojenih več kot 30 ljudi, med njimi številni na smrtno kazen. Med žrtvami teh procesov je bilo kar 9 kemikovi. Predhodnik dachauskih procesov je bilo sojenje za delovno nesrečo v hrastniški steklarni, ki jo je oblast želela prikazati kot sabotažo, vendar takrat tožilcu ni uspelo dovolj dobro utemeljiti obtožnice, zato so sodbo razveljavili. V nadaljevanju so preiskovalci natančno preverili pred- in medvojno delovanje tistih, ki so bili povezani s hrastniško steklarno in pri tem opazili povezave med strokovnjaki na nekaterih pomembnih položajih, ki jim je bilo skupno to, da so preživeli obdobje internacije $\mathrm{v}$ koncentracijskem taborišču Dachau (in nekateri Buchenwald), ter večinoma sodelovali kot tehnično osebje pri poskusih na ljudeh ali v laboratoriju taboriščne bolnišnice. Zaradi ustreznih znanj so to pogosto bili kemiki, zaradi pomembnosti dela, ki so ga opravljali, pa so $\mathrm{v}$ primerjavi z ostalimi interniranci imeli ugodnejše življenj-

I Obtoženi so bili kemiki Karel Barle, Branko Diehl, Boris Fakin, Mirko Košir, Boris Krajnc, Vladimir Ličen, Mitja Sark in Milan Stepišnik. Mirko Pibernik je umrl med preiskavo, torej pred vložitvijo obtožnice. ske razmere. Obtožnica jih je prikazala kot tajne agente Gestapa, ki so jih nemške oblasti poslale na prešolanje v taborišča, da bi se tam pomešali med rojake, pridobivali podatke in se kasneje vrnili v Slovenijo ter nadaljevali z delom kot agenti. Po vojni naj bi tujim agenturam posredovali podatke o stanju v Sloveniji in izvajali sabotaže. Hkrati naj bi se ti ,agenti' medsebojno podpirali pri pridobivanju vodilnih položajev $\mathrm{v}$ gospodarstvu in politiki.

Eden od obtoženih kemikov je bil Boris Krajnc, ki je komaj dobro leto in pol pred aretacijo postal docent za področje biokemije na Tehniški fakulteti ljubljanske univerze. Po Richardu Klemnu, ki je emigriral že leta $1942^{1}$, je bil Krajnc naslednji učitelj ljubljanske univerze, ki se je ukvarjal z biokemijskimi temami, vendar je Klemen po imenovanju za privatnega docenta predaval predvsem encimatiko in kmetijsko kemijo, Krajnc pa prav biokemijo, zato ga Fakulteta za kemijo in kemijsko tehnologijo Univerze v Ljubljani vodi kot docenta za področje biokemije (ob njegovem imenovanju področje habilitacije ni bilo definirano).

Sojenje Borisu Krajncu in drugim obsojenim na dachauskih procesih je bilo $\mathrm{v}$ naslednjih desetletjih večkrat strokovno obdelano in večina sodb je bila končno razveljavljenih leta 1976. Čeprav je res, da so nekateri slovenski 
kemiki sodelovali v psevdomedicinskih raziskavah $\mathrm{v}$ taborišču Dachau, njihovo sodelovanje pri tem ni bilo prostovoljno, oziroma dela niso mogli zapustiti po lastni želji, kot neutemeljene pa so se izkazale tudi druge točke obtožnic.

\section{2. Življenjska pot Borisa Krajnca}

Boris Krajnc (slika 1) se je rodil 25. decembra 1913 na Reki na Hrvaškem, kjer je bil oče Ivan posojilniški uradnik. Družina se je kmalu preselila v Celje, od koder je bila mati Franja, rojena Božič. Boris je v Celju opravil 5 razredov osnovne šole (1925) in nato 8 razredov realne gimnazije (maturiral je junija 1933 kot Borislav Krajnc). Oče je umrl decembra 1931, tako da je Boris ostal sam z mamo.

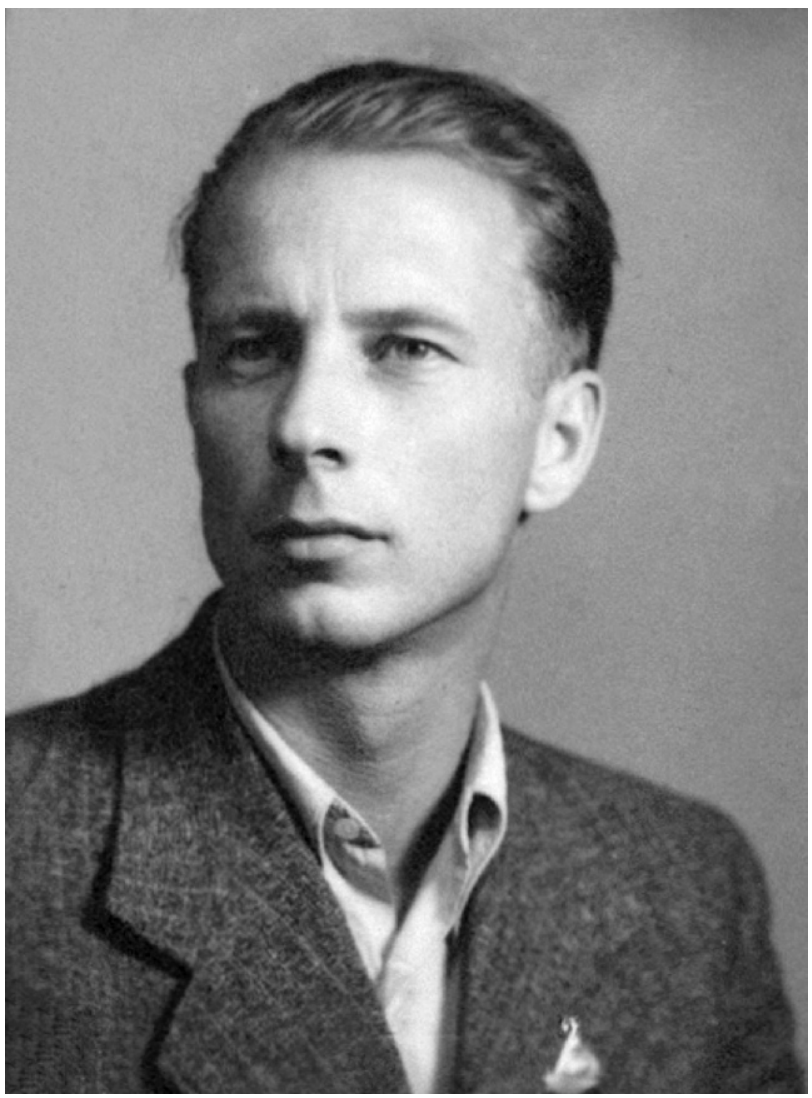

Slika 1: Fotografija B. Krajnca iz osebne izkaznice, datirane s 3. 3. 1946. Vir: Arhiv Republike Slovenija, SI AS 1931, RSNZ SRS, Dachauski procesi, šk. 512.

Leta 1933 se je vpisal na ljubljansko univerzo, kjer je na Tehniški fakulteti študiral kemijo. Diplomiral je pod mentorstvom Maksa Samca z nalogo »Metiliranje škrobovih substanc«. Strokovni del diplomske naloge je zagovarjal 29. septembra 1938, diplomska listina pa je datirana s 3 . julijem 1939.

Študijski kolega Borisa Krajnca je bil Mirko (Friderik) Dermelj (1914-2018), nečak Maksa Samca. Ko sta zaključila študij (na isti dan), je Samec Dermelja poslal na izpopolnjevanje $\mathrm{v}$ Heidelberg ${ }^{\mathrm{II}}$, njegovega prijatelja Krajnca pa v Berlin. S štipendijo v okviru mednarodne izmenjave študentov je od novembra 1938 do maja 1939 deloval na Kemijskem inštitutu cesarja Wihelma (nem.: Kaiser-Wilhelm-Institut für Chemie) v laboratoriju dr. Kurta Hessa (1888-1961), ki je bil zagret pristaš nacionalsocializma ${ }^{\text {III }}$. Skupaj s Hessom je Krajnc leta $1940 \mathrm{v}$ reviji nemškega kemijskega društva »Berichte der deutschen chemischen Gesselschaft« objavil najprej kratek članek o določanju končnih skupin sestavin škroba ${ }^{2}$, nato pa v isti reviji še članek ${ }^{3} \mathrm{z}$ naslovom $» O$ visokometiliranem škrobu in vprašanje njegovih cepitvenih sladkorjev« (soavtor tudi Hans Albrecht Schulze). V drugem članku je Krajnc zapisan napačno (Kranjc) in brez afiliacije ljubljanske univerze.

Mirko Dermelj je ostal v Nemčiji do septembra, Krajnc pa le do maja 1939, torej 7 mesecev $^{\text {IV }}$. Nato je Krajnc v starojugoslovanski vojski odslužil 9-mesečni »dijaški rok« v Kruševcu v Srbiji in to s položenim izpitom za rezervnega oficirjav; njegov zadnji čin je bil podnarednik. Vojaški rok sta služila $z$ Dermeljem v isti vojašnici in sočasno, prav tako sta se leta 1940 oba zaposlila v železarni na Jesenicah. Krajnc je 15. septembra 1940 postal obratni asistent v Kranjski industrijski družbi (KID), ki je upravljala z železarno, vendar je bilo njegovo delovno mesto v opekarni. Pred izbruhom 2. svetovne vojne sta bila z Dermeljem in verjetno še nekaterimi drugimi slovenskimi kemiki mobilizirana v vojno-tehnični zavod Obiličevo v Kruševcu (Srbija). Ker pa so Kruševac že prvi dan vojne bombardirali, so se vojaki odpravili proti Sara-

II Dermelj se je usposabljal pri dr. Karlu Freudenbergu na Raziskovalnem inštitutu za kemijo lesa in polisaharidov na Univerzi v Heidelbergu do avgusta 1939. Za bivanje v Nemčiji je prejel nemško štipendijo. Ob izbruhu 2. svetovne vojne je moral zapustiti Heidelberg zaradi bližine Francije, ki je vstopila v vojno z Nemčijo ${ }^{4,5,6}$. Na zaslišanju novembra 1947 pa je Dermelj izjavil, da sta imela s Krajncem štipendijo ljubljanske univerze in da se je vrnil v Ljubljano že junija 1939. Ko so ga preiskovali zaradi očitanega medvojnega oportunizma, je izjavil, da je v Heidelbergu 'zagovarjal svojo diplomsko nalogo' in da se Samec in Freudenberg strokovno nista dobro razumela.

III Hess je na inštitut prišel leta 1921 in ustanovil oddelek za kemijo celuloze. Leta 1931 je odšel v industrijo (IG Farben), a je ohranil status gostujočega sodelavca in še naprej vodil oddelek. Njegova nacistična usmerjenost se kaže s tem, da je prijavil fizičarko Lise Meitner, ki je bila avstrijska judinja - sicer pa tesna sodelavka direktorja inštituta, nobelovca Otta Hahna - verjetno v želji, da bi zamenjal Hahna na direktorskem mestu?

IV V času izpopolnjevanja v Berlinu je prišlo verjetno do nekega nesoglasja, kar je mogoče razbrati iz navedbe Borisa Krajnca, ko je med preiskavo za Diehl-Oswaldov proces opisal značaj Maksa Samca. Tam je omenil, da so se stiki med Samcem in Hessom ohladili prav zaradi Krajnčevega dela v Berlinu.

V Rekruti s končano srednjo šolo so do leta 1940 lahko za 9 mesecev vstopili v šolo za rezervne vojaške starešine, potem pa so polagali izpit. Če ga niso opravili, so morali nadaljevati s služenjem do dopolnjenih 14 mesecev (običajni rok je trajal 18 mesecev, v letalstvu in mornarici pa 2 leti). Septembra 1940 so z uredbo dijaški rok podaljšali na 12 mesecev, če so bili naborniki neuspešni pri končnem izpitu, pa so morali ostati $\mathrm{v}$ vojski skupaj 18 mesecev, medtem ko je bil redni rok v vseh rodovih vojske 2 leti $^{8}$ 
jevu ${ }^{\text {VI }}$. Ob kapitulaciji jugoslovanske armade 17. 4. 1941 sta bila Krajnc in Dermelj torej v Sarajevu, od koder sta se uspela preko Zagreba vrniti na Jesenice. Od oktobra 1941 je bil Krajnc povezan z delovanjem Osvobodilne fronte na Jesenicah, a so ga nekaj mesecev kasneje aretirali. Od 22. januarja do 16. marca 1942 je bil zaprt v Begunjah, kjer so ga pogosto zasliševali, od tam pa je bil interniran v Dachau.

V koncentracijsko taborišče Dachau je prispel 18. marca 1942 in ostal zaprt do 22. decembra 1943. Po Krajnčevi navedbi v uslužbenskem listu ${ }^{\mathrm{VII}}$ je bil zapor v Dachauu spremenjen $\mathrm{v}$ konfinacijo, od koder naj bi pobegnil novembra 1944 in se vrnil na Jesenice. Pridružil se je partizanskemu Jeseniško-bohinjskemu odredu, od decembra 1944 pa je bil referent za industrijo pri Okrožnem odboru Osvobodilne fronte Jesenice.

V času, ko je bil Krajnc v taborišču Dachau, ga je verjetno trikrat obiskal študijski kolega in prijatelj Mirko Dermelj ${ }^{\mathrm{VIII}}$, prvič za novo leto 1944. Ob tem je Krajnc dobil prost dan, ko je lahko odšel v München in tam tudi prespal. Dermelju je ob prvem obisku pripovedoval o poskusih s podhlajevanjem, pri katerih je sodeloval. Drugič je $\mathrm{z}$ Dermeljem potovala tudi ,starejša kemičarka Zakrajškova iz Maribora' (Marija Zakrajšek, diplomirala 1936, torej dve leti pred Krajncem in Dermeljem ${ }^{\mathrm{IX}}$. Iz zapisnikov zaslišanj Borisa Krajnca v letih 1947/48 je razvidno, da sta ga obiskali tudi mama in kasnejša žena in da je ob teh priložnostih vedno lahko prespal v Münchnu v hotelu.

O njegovem delu v Dachauu, ki je podrobneje razloženo v nadaljevanju, je znano, da je večino časa sodeloval pri razvoju preparata za strjevanje krvi v skupini, ki jo je vodil Sigmund Rascher, kasneje pa je vodenje prevzel Kurt Plötner.

Da status Borisa Krajnca ni ustrezal klasični predstavi o nekom, ki je bil zaprt v taborišču Dachau, govori podatek, da je bil konec maja 1944 na dopustu doma, a se je nato vrnil v Dachau. V Slovenijo se je dokončno vrnil 7. novembra 1944 na osnovi ponarejenega dokumenta ${ }^{\mathrm{x}}$, ki so

VI Vodja generalštaba je $\mathrm{z}$ odhodom jugoslovanske vlade in kralja v Grčijo prevzel general Kalafatović, vrhovno poveljstvo pa je bilo nameščeno v bližini Sarajeva ${ }^{9}$. Nemško letalstvo je Sarajevo bombardiralo 12. in 13. aprila, 15. aprila pa so nemške enote vkorakale v mesto ${ }^{10}$.

VII Personalna mapa v arhivu Univerze v Ljubljani št. 87/1167.

VIII V prepisu zasebnega pogovora z Mirkom Dermeljem iz leta 2012, ki mi ga je posredovala dr. Tatjana Peterlin-Neumeier, sta omenjena dva obiska, $v$ zaslišanjih po 2 . svetovni vojni pa je izjavil, da je bil na obisku trikrat.

IX Po Dermeljevem pripovedovanju (novembra 2012) je ob drugem obisku Krajnc iz taborišča pretihotapil revolver, ki naj bi ga dobil v zameno za kos kruha pri zaporniku, ki je delal zunaj taborišča pri čiščenju posledic letalskih bombardiranj, in majhen radijski sprejemnik, ki so ga zaporniki naredili iz elektrotehniškega materiala, zbranega iz sestreljenih letal. Radijski aparat je Dermelj kasneje predal partizanom. Krajnčeva žena pa omenja v zaslišanju dne 22. 11. 1949 dve ali tri pištole, ki naj bi jih preskrbel profesor kemije Boris Škerlj iz Kranja (ki je med vojno delal v Münchnu) in preko Borisa Krajnca posredoval Dermelju.

X V Janžekovičevem poročilu ${ }^{11}$ iz leta 1970 je napačno navedeno, da mu ga organizirali sodelavci OF z Jesenic in mu ga je prinesel Milan Stepišnik, ko se je oktobra 1944 vrnil z dopusta. Takoj po prihodu na Jesenice je Krajnc odšel preko zveze na Črnem vrhu nad Jesenicami k partizanom ${ }^{\mathrm{xI}}$.

Po osvoboditvi je bil Boris Krajnc od 25. 5. 1945 do 31. 1. 1946 vršilec dolžnosti šefa odseka za kemijsko industrijo na Ministrstvu za industrijo in rudarstvo Ljudske republike Slovenije. Kaže, da se je tam zavzemal za odprtje tovarne za predelavo magnezita (iz njega bi lahko pridobivali magnezijev oksid, uporaben za proizvodnjo ognjeodporne opeke za plavže), ohranjen pa je tudi njegov referat o hidrolizi lesa. Junija 1945 se je na Jesenicah poročil z Ivanko Zvezda (1919-2012).

Doktorsko disertacijo z naslovom »Končne skupine in struktura škrobovih komponent« je Boris Krajnc zagovarjal 10. novembra $1945^{\mathrm{XII}}$. V nalogi je Maks Samec, ki po osvoboditvi ni več smel delovati na univerzi, naveden kot delovni mentor, Marij Rebek pa kot ,referent' (mentor). Zagovor je bil samo en mesec pred predčasno upokojitvijo Marija Rebka, po kateri se je odselil v Gradec, kjer je še naprej predaval. Nenavadno je, da Krajnc po vrnitvi iz Berlina maja 1939 sploh ni več delal na tematiki svoje doktorske naloge, tako da disertacija temelji na rezultatih, dobljenih v obdobju 7-mesečnega podiplomskega usposabljanja. Njegova disertacija, ki jo hrani NUK, ima le 8 stra-

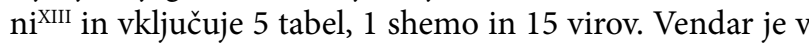

je uporabil ponarejeno potrdilo, ki mu ga je priskrbel Stepišnik za dopust maja 1944. V resnici je to potrdilo dobil šele po Stepišnikovi vrnitvi z dopusta konec oktobra 1944, uporabil pa ga je za pobeg iz Dachaua. Kot je izjavil v preiskovalnem postopku, je pobeg izvedel v času, ko je bil vodja skupine, dr. Plötner, v 'Berlinu', z 'Lebersdorferjem’ pa se je dogovoril, da bi v primeru, če bi kdo po telefonu preverjal Krajnčev odhod, rekel, da je vse v redu. Gre za Josefa (Seppa) Leberstorferja (roj. 1912), študenta medicine z Dunaja, ki je kot zapornik delal na rentgenskem in zobnem oddelku, sicer pa je bil predvojni komunist, ki so ga v Dachau privedli že junija 1941 (izpuščen je bil 10. 11.1944). Od maja 1944 je Leberstorfer bil kapo (nadzorni zapornik) v stavbi, kjer je bila taboriščna bolnišnica $\mathrm{z}$ laboratoriji. Plötner je poleg vodenja raziskovalne skupine v Dachauu bil na mestu taboriščnega zdravnika v Sachsenhausnu nedaleč od Berlina. Vendar tam ni zdravil, pač pa je verjetno zgolj opravljal poskuse na zapornikih $^{12}$. Da je bil 'v Berlinu', verjetno pomeni, da je bil v taborišču Sachsenhausen.

XI Kot opisuje Mirko Dermelj (gl. opombo VIII), je prenočil v počitniški hiši družine Zvezda, od tam pa je ponj prišel nekdo od partizanskih sodelavcev. Enota naj bi se kasneje zadrževala na področju Pokljuke.

XII Promocija doktorata je bila šele 5. oktobra 1946, ko je bil Krajnc že docent. V seznamu doktorjev UL je listina vpisana pod št. 649, z dopisom THF (Tehniška fakulteta).

XIII Za primerjavo sem preveril nekaj drugih doktoratov Tehniške fakultete iz tistega obdobja. Istega leta (20. decembra 1945) je iz kemije doktoriral Božo Težak (1907-1980), kasnejši profesor zagrebške univerze, in sicer z disertacijo "Istraživanje taložnih struktura barium sulfata «. Težak je do takrat objavil 11 strokovnih in znanstvenih člankov, a je njegova naloga obsegala 69 strani $^{13}$, NUK pa pod tem naslovom in z letnico 1945 hrani samo 3-stranski separat, ki nima značilnosti disertacije. Eno leto prej je doktoriral Ludvik Žagar z nalogo »Primerjava amilopektinov koruznega in krompirjevega škroba«, NUK pa pod tem naslovom hrani "odlomke iz inavguralne disertacije « v obsegu 5 strani. Disertacij (niti izvlečkov) kemikov, ki so promovirali do leta 1955, NUK ne hrani, z izjemo nekaterih, ki so razširjene izvlečke objavili v Razpravah SAZU (Dušan Hadži, Drago Lebez). 
predvojnem in zgodnjem povojnem obdobju bilo običajno, da kot tiskana publikacija izide le kratek izvleček, ki ga knjižničarji včasih označujejo kot, odlomki iz avguralne disertacije.

Senat Univerze v Ljubljani je 11. decembra 1945 sprejel pobudo Tehniške fakultete in predlagal »šefa odseka za kemično industrijo pri min. industrije in rudarstva tov. ing. Borisa Krajnca za univerzitetnega docenta za biokemijo «. Nato je 5. januarja 1946 minister za prosveto ${ }^{\mathrm{XIV}}$ Krajnca $\mathrm{z}$ odlokom imenoval za univerzitetnega docenta na Tehniški fakulteti ljubljanske univerze (slika 2). S februarjem 1946 se je Krajnc zaposlil kot docent, razvrščen v VII. položajno skupino, novembra 1947 (ko je bil že v zaporu) pa je napredoval v docenta II. Univerzi je predložil potrdilo o nekaznovanju, datirano s 25. 3. 1947.

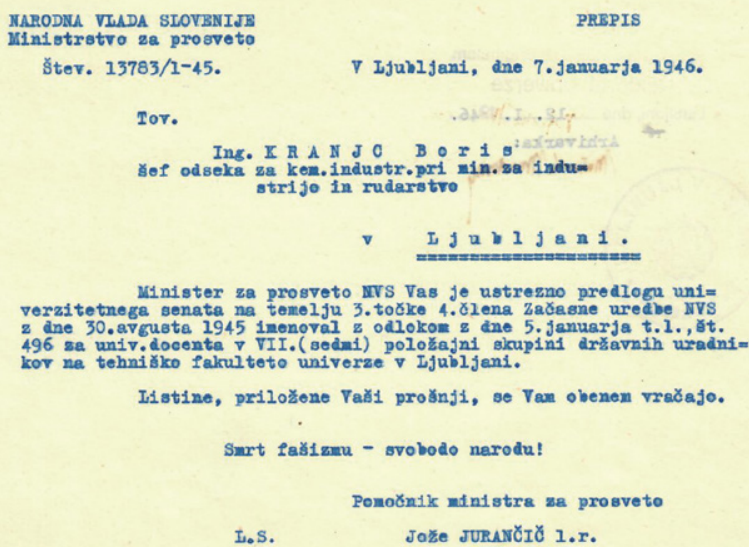

Slika 2: Dopis Ministrstva za prosveto o imenovanju Borisa Krajnca za docenta na predlog senata ljubljanske univerze. Vir: Zgodovinski arhiv in muzej Univerze v Ljubljani (ZAMU) IV - 87/1167, personalna mapa Borisa Krajnca.

V seznamu predavanj Univerze v Ljubljani za poletni semester 1945/46 je Boris Krajnc naveden kot edini član Inštituta za biokemijo $\mathrm{z}$ redno zaposlitvijo, ob njem pa je kot honorarni predavatelj še inž. Josip Šlajmer, zadolžen za predmet Tehnična mikrobiologija. Krajnc je naveden $s$ predmetom Izbrana poglavja iz biokemije ( $2 \mathrm{~h}$ predavanj tedensko in $15 \mathrm{~h}$ biokemijskega praktikuma, ki se je izvajal v laboratoriju za organsko kemijo).

$\mathrm{Na}$ ravni države je bil avgusta 1946 predpisan učni načrt, ki je za študente kemije predvideval v 2. letniku predmet Tehnično mikroskopiranje, $v 4$. letniku pa Izbrana poglavja iz biokemije in encimatike ter Tehnično mikrobiologijo. Določen je bil tudi učni načrt za ločen dvoletni študij farmacije, ki pa takrat še ni vseboval biokemije. V zimskem semestru 1946/47 je Krajnc tako naveden pri

XIV Glede na izjavo Borisa Fakina med preiskavo in obravnavo na dachauskem procesu naj bi si Krajnc želel priti na univerzo, zato ga je "priporočil ministru za prosveto kot najboljšega znanstvenega delavca in partijca ${ }^{14}$. predmetu Izbrana poglavja iz biokemije in encimatike $(2 \mathrm{~h}$ predavanj, $5 \mathrm{~h}$ vaj), v poletnem semestru pa pri predmetu Tehnična kataliza ( $2 \mathrm{~h}$ predavanj).

V zimskem semestru 1947/48 je Krajnc pokrival predmet Tehnologija katalitskih procesov $(3 \mathrm{~h}$ predavanj, $20 \mathrm{~h}$ vaj). Bolj biološke in biokemijske vsebine so $\mathrm{v}$ tem semestru poleg inž. Šlajmerja izvajali še drugi zunanji predavatelji: Jože Lazar Botanične mikroskopsko-anatomske vaje ter vaje iz Sistematike rastlin, Peter Lenče Anatomijo in fiziologijo človeka za farmacevte, Albin Seliškar z Medicinske fakultete pa Fiziološko kemijo.

Glede Krajnčevega raziskovalnega dela v letih 194647 ni veliko podatkov, iz naslovov diplomskih nalog ${ }^{\mathrm{xv}}$ pa je razvidno, da je nadaljeval raziskave o vlogi pektina na strjevanje krvi, kar je bila glavna tema pri njegovem strokovnem delu v Dachauu. Prvo ohranjeno diplomsko delo (Bojan Držaj, Vpliv pektina na koagulacijo krvi po mikrometodi, 1947) vključuje izolacijo in karakterizacijo pektina iz jabolčnih tropin ter frakcioniranje različno dolgih fragmentov pektina, čemur je sledila analiza delovanja na strjevanje krvi. Rezultati so pokazali, da strjevanje krvi pospešujejo le razgradni produkti pektina, ne pa sam pektin, ne glede na dolžino njegove verige. Drugo diplomsko delo (Jelka Ružič: Vpliv razgradninskih produktov pektina na I. fazo koagulacije krvi, 1949) je vključevalo kislinsko hidrolizo pektina, s čimer je nastala digalakturonska kislina. Nato je študentka preverjala njen vpliv na hitrost strjevanja krvi v razmerah in vitro. Dodatno je izolirala še trombin in trombokinazo in ugotavljala morebitno spremembo hitrosti strjevanja krvi. V delu, kjer je določila optimalno koncentracijo digalakturonske kisline, je omenila, da se rezultat ujema z rezultati njenega predhodnika (verjetno Držaja).

Iz obveščevalnih podatkov Udbe (obveščevalec »Milko«, prim. opombo XV) je razvidno, da se je Krajnc zavzemal tudi za razvoj postopkov aromatizacije nafte, kar naj bi bil osnovni problem slovenske kemijske industrije. Sprva je bil doc. Škerlak ${ }^{\mathrm{XVI}}$ temu nenaklonjen, ker naj bi bilo zelo negotovo, če je v doglednem času možno doseči zadovoljive rezultate, kasneje pa je podprl Krajnca in prevzel pobudo pri pogovorih s predstavnikom republiške planske komisije, tako da je ta tema prišla v petletni plan. Obveščevalec meni, da bi uspeh aromatizacije velenjskega lignita predstavljal za slovensko industrijo pomemben dosežek.

XV V knjižnici UL FKKT sta arhivirani samo dve nalogi, pri katerih je Krajnc omenjen kot mentor, čeprav je iz obveščevalnih podatkov (23.4.1948, obveščevalec 'Milko', ki je moral biti zaposlen na fakulteti, saj je natančno poznal vsebino pogovorov med Krajncem in Škerlakom) [SI AS 1931, dosje B. Kranjca, str. 365] mogoče razumeti, da je pod njegovim mentorstvom bilo izvedenih 5 diplomskih nalog na temo pektina. Glede morebitnih ostalih treh nalog ni mogoče ugotoviti, ali so sploh obstajale.

XVI Tibor Škerlak (1913-1992) je doktoriral na Tehniški visoki šoli v Münchnu, leta 1945 pa je postal docent za teoretično in fizikalno kemijo na Tehniški fakulteti UL. Zaradi podpore resoluciji Informbiroja je bil zaprt na Golem otoku (1949-1951). Kasneje se je preselil v Sarajevo, kjer je bil na univerzi leta 1954 izvoljen v naziv izrednega profesorja. Ustanovil je katedro za fizikalno kemijo, ki jo je tudi vrsto let vodil. $V$ času vojne v Bosni in Hercegovini ga je smrtno ranil ostrostrelec ${ }^{15}$. 
Krajnca so aretirali 27. oktobra 1947. Na Diehl-Oswaldovem procesu aprila 1948 so ga obsodili na smrt. Sodbo naj bi izvršili 12 . maja $1948^{\mathrm{XVII}}$, a obstajajo indici, ki kažejo, da so nekateri obsojenci s tega procesa ostali zaprti do leta 1950, ko so jih ustrelili na območju Kočevskega Roga. Za Krajnca se je zdelo, da je podatek o izvršeni sodbi leta 1948 verodostojen. Pokopali naj bi ga bržkone na neoznačenem mestu na ljubljanskih Žalah ${ }^{16}$. Vendar pa sem v Arhivu Republike Slovenije našel rokopis ${ }^{\mathrm{XVIII}}$ Borisa Krajnca iz zapora, datiran z 20. majem $1948^{\mathrm{xIX}}$. To je tudi zadnji Krajnčev tekst $v$ arhivu, vsekakor pa je bila izjava podana dober teden po tem, ko naj bi Krajnca usmrtili.

Zaradi obsodbe je pristojni minister izdal odločbo o prenehanju delovnega razmerja, rektor pa je na seji senata UL 22. junija 1948 lahko samo sporočil, da sta Boris Krajnc in Mirko Košir prenehala biti člana profesorskega kolegija ${ }^{17}$.

S Krajnčevo aretacijo ni jasno, kdo, če sploh, je prevzel njegove predmete $\mathrm{v}$ študijskem letu 1947/48. Iz seznamov predavanj UL je razvidno, da se je predmet Izbrana poglavja iz biokemije in encimatike ponovno izvajal $\mathrm{v}$ študijskem letu 1948/49, ko je predmet predaval Dušan Stucin z Medicinske fakultete, enako naslednja tri leta, potem pa je prišlo do reorganizacije študijev kemije, po kateri biokemije niso več predavali do 1956/57, ko se ponovno pojavi, tokrat kot ,višji kurz' (Izbrana poglavja iz biokemije in encimatike, D. Stucin z Medicinske fakultete).

\section{Krajnčevo delovanje $v$ taborišču Dachau}

Kot sledi iz analize dachauskih procesov ${ }^{11}$, ki jo je pripravila takoimenovana "Janžekovičeva komisija «x

XVII Vojaško sodišče v Ljubljani je 16. junija 1948 poslalo matičnemu uradu na Reki dopis, ki naj bi služil za vpis Krajnca v knjigo umrlih. V dopisu je navedeno, da je bil Krajnc justificiran 12. maja 1948. Z Reke so sporočili, da za vpis v knjigo umrlih niso pristojni, temveč morajo to izvesti v Ljubljani. V izpisku iz mrliške matične knjige iz Ljubljane je navedeno, da je Krajnčeva smrt bila vpisana leta 1950. Datum smrti je 12.5.1948, kraj smrti pa Miklošičeva 4, to je naslov nekdanjih ljubljanskih zaporov za sodno palačo (danes sta tam parkirna hiša in hotel).

XVIII Vprašanja so se nanašala izključno na eno osebo, 'Žukova', ki je bil med vojno zaprt v taborišču Dachau, po Krajnčevem vedenju pa naj bi bil po osvoboditvi 'direktor na radiu Beograd'. Jevgenij Andrejevič Žukov (1898-1959) je bil predvojni novinar, ki je iz Beograda pokrival področje Balkana. Že leta 1925 je bil med soustanovitelji Zveze ruskih pisateljev in novinarjev v Jugoslaviji, leta 1928 pa je ustanovil koncertno agencijo Jugokoncert, ki je organizirala gostovanja številnih vidnih umetnikov v Beogradu in drugod po Jugoslaviji. Med vojno je bil interniran $\mathrm{v}$ Dachau, po vojni pa je nadaljeval $\mathrm{z}$ novinarskim in organizacijskim delom na področju kulture v Beogradu. Žukov je bil v rednih stikih z Justinom Ažmanom iz Krope, prav tako nekdanjim internirancem v Dachauu. V času Krajnčevega zadnjega zaslišanja so Žukova preverjali glede delovanja v Dachauu, kjer je bil sobni starešina. Obtožb je bil oproščen šele po letu $1950^{18}$.

XIX Naknadno sem ugotovil, da je zapisnik našla že Emilija Snoj, ki je leta 2001 zagovarjala diplomsko nalogo na temo dachauskih procesov ${ }^{19}$.

XX Gre za petčlansko komisijo, ki so jo sestavljali pravnik Ivo Janžekovič (predsednik komisije, sicer predsednik Republiškega sveta Zveze sindika- bil Krajnc po prihodu v Dachau sprva dodeljen v različne taboriščne delovne skupine, nato pa je bil januarja 1943 premeščen v ,raziskovalno postajo' v skupino dr. Sigmunda Rascherja, kjer naj bi najprej opravljal analize krvi, kasneje pa sodeloval pri testiranju preparata za strjevanje krvi.

Krajnc je v okviru preiskave za dachauski proces povedal, da je po prihodu v Dachau tri mesece delal v skupini za gradnjo barak, nakar ga je Martin Presterl ${ }^{\mathrm{XXI}}$ uspel premestiti na zajčjo farmo, kjer je dva meseca prevažal krmo in gnoj. Sledilo je delo v proizvodnji, kjer naj bi izdelovali lesene igrače, in $v$ mizarski delavnici, nato pa je bil premeščen $\mathrm{k} d r$. Rascherju po navodilu taboriščne pisarne za razporejanje dela (Arbeitseinsatz). V argumentaciji razveljavitve sodbe v Diehl-Oswaldovem procesu (razveljavitev je datirana s 7. aprilom 1976) je natančneje navedeno, da je bil Krajnc premeščen $\mathrm{v}$ gospodarske obrate taborišča septembra 1942, sredi januarja 1943 pa v skupino dr. Rascherja, kjer je po Krajnčevi navedbi izvajal »določitve mlečne

tov in $\mathrm{v}$ predhodnem mandatu poslanec $\mathrm{v}$ republiškem zboru slovenske skupščine), Francka Strmole (nekdanja predsednica Ljudske mladine Slovenije, pravnica, $\mathrm{v}$ predhodnem mandatu poslanka $\mathrm{v}$ republiškem zboru, kasneje predsednica vrhovnega sodišča SRS od 1981 do 1993), Ivan Ros (pravnik, poslanec, predsednik skupščinskega odbora za organizacijsko-politična vprašanja), Savo Šifrer (pravnik, sodnik, poslanec v predhodnem sklicu skupščine, član Višjega gospodarskega sodišča SRS, kasneje, leta 1959, predsednik sodnega senata, ki je obsodil Jožeta Pučnika zaradi protidržavnega delovanja) in Rihard Knez (pravnik, sodnik, od leta 1947 član vrhovnega sodišča SRS, član sodnega senata 1948 na sojenju proti »Bitenčevi skupini«, obtoženi protidržavnega delovanja - prim. http://nszaveza.github.io/articles/9-slike-iz-zadnjega-dejanja/, tajnik komisije za prošnje in pritožbe pri republiškem izvršnem svetu). Komisija je z delom začela 26. maja 1969 in končno poročilo izdala 30. marca 1970. Sestavo komisije je določil predsednik izvršnega sveta slovenske skupščine Stane Kavčič, ki je dobil nalogo, da razišče nejasnosti glede dachauskih procesov, od vodstva Zveze komunistov Slovenije. Pri delu je imela komisija dostop do celotnega gradiva, okrog 30.000 tipkanih strani, in do predhodnih analiz procesov, ki sta jih pripravila leta 1951 major Udbe Anton Debevec (1923-2002) in 1968 major Stane Škraba (prav Škraba, takrat še v rangu kapetana, je opravil hišno preiskavo ob aretaciji Borisa Krajnca leta 1947). Janžekovičeva komisija je imela 9 sej, vsak član pa si je moral na osnovi gradiva izdelati najprej lastno mnenje o procesih. $\mathrm{Na}$ osnovi teh neodvisnih mnenj so oblikovali končno poročilo, v katerem opisujejo predvsem značilnosti taborišč in njihovo upravljanje, povojne gospodarske sabotaže, ki so bile povod za začetek preiskave, značilnosti preiskovalnega postopka in glavne obravnave, nato pa so se člani posvetili posameznim obsojencem in se kritično opredelili do dokazov, uporabljenih v procesih. Kot je nakazala že Škrabova analiza, je tudi Janžekovičeva komisija ugotovila, da preiskave in sojenja niso bili izvedeni ustrezno.

XXI Josef (Martin) Presterl (1916-1948?) je bil soobtoženec na dachauskem procesu, sicer pa je bil avstrijski predvojni komunist, španski borec in novinar. Po vojni je simpatiziral z jugoslovansko uradno politiko. Po preiskovalnem zaporu v Gradcu je bil od 22. 2. 1942 zaprt v taborišču Dachau. Leta 1946 je z jugoslovansko pomočjo v Avstriji ustanovil založbo Kristall-Verlag in leta 1947 izdal brošuro »2000 kilometrov po novi Jugoslaviji«, v kateri je poudarjal naprednost in zanos, ki naj bi vladal v takratni Jugoslaviji. Avgusta istega leta je v dogovoru z jugoslovanskim konzulatom ustanovil tiskovno agencijo, ki naj bi dvakrat mesečno izdajala bilten, ki bi 'ustrezno' predstavljal dosežke v Jugoslaviji in sosednjih socialističnih državah. Aretirali so ga na železniški postaji v Mariboru 27. oktobra 1947. Več o njegovem delu je razvidno iz članka Heima Halbrainerja ${ }^{20}$. Postal je ključna priča tožilstva, saj je trdil, da je v vlogi agenta tuje obveščevalne službe razpredel agenturne stike z drugimi obtoženimi, ki so pred tem bili agenti Gestapa, tako kot on sam. 
kisline, klora, krvnega sladkorja, beljakovin, števila rdečih krvnih telesc in drugih sestavin v krvi«. Meril naj bi tudi temperaturo in sodeloval pri izdelavi pektinskih preparatov.

Čeprav je Krajnc v svojem življenjepisu, ki ga je pripravil ob zaposlitvi na ljubljanski univerzi, iz dachauskega obdobja omenjal samo delo na preparatu za strjevanje krvi, je torej gotovo sodeloval tudi pri zadnjih poskusih ohlajanja in ponovnega ogrevanja (t.im. hipotermični poskusi), po katerih je Rascher verjetno najbolj znan ${ }^{\mathrm{xxII}}$.

Krajnčeva vključenost v poskuse s podhlajevanjem je zelo verjetna glede na časovni razpored raziskav Rascherjeve skupine $\mathrm{v}$ koncentracijskem taborišču Dachau. V času, ko naj bi Krajnc začel delati pod Rascherjevim vodstvom (januar 1943) so potekali še zadnji poskusi s hipotermijo, predvsem $\mathrm{v}$ povezavi $\mathrm{z}$ različnimi postopki ogrevanja po izpostavitvi mrazu. Večina predhodnih raziskav s potapljanjem $\mathrm{v}$ mrzlo vodo naj bi namreč bila zaključena že septembra ali oktobra 1942, kot je mogoče razbrati iz korespondence Rascherja s Himmlerjem. Oktobra je namreč Rascher oddal zaključno poročilo o opravljenih poskusih, v katerem navaja, da bi bilo treba zgolj še natančneje ugotoviti, kateri načini ogrevanja bi bili najprimernejši, kar je Himmler nato tudi izrecno podprl. Vsi poskusi naj bi bili zaključeni do maja 1943. Da hipotermični poskusi v Krajnčevem obdobju niso več intenzivno potekali, priča tudi to, da so vodje raziskave o hipotermiji (prof. dr. Holzlöhner, dr. Finke in dr. Rascher) o rezultatih poročali že konec oktobra 1942 na sestanku v Nürnbergu.

$\mathrm{V}$ hipotermičnih poskusih so zapornike potapljali $\mathrm{v}$ mrzlo vodo in analizirali njihove odzive: merili so telesno

XXII Sigmund Rascher (1909-1945) je opravil državni zdravniški izpit v Münchnu leta 1936. Ob tem je pridobil tudi doktorski naziv na osnovi raziskovalnega dela, ki je bilo s področja diagnostike nosečnosti na osnovi oblike kristala bakrovega klorida $\left(\mathrm{CuCl}_{2}\right)$. Ta v prisotnosti organskih snovi kristalizira $\mathrm{v}$ paličasti obliki, a naj bi bila oblika odvisna od tipa organske snovi. Tako naj bi določeni hormoni v vzorcih urina nosečnic dali specifične oblike kristalov. To naj bi bilo mogoče samo ob izredno natančni izvedbi kristalizacij in je bilo praktično neponovljivo. Prvo delovno mesto je dobil kot neplačani asistent na oddelku za kirurgijo ene od münchenskih bolnišnic, tako da je konec leta 1937 dobil dovoljenje za opravljanje zdravniškega poklica. Že pred tem pa je prejel enoletno štipendijo raziskovalnega sklada za izvedbo raziskave na temo diagnostike raka na osnovi kristalizacijskega vzorca $\mathrm{CuCl}_{2}$. Dobljenim rezultatom že ob objavi veliko strokovnjakov ni verjelo, danes pa velja, da so potvorjeni. Rascherjeva partnerka Karoline Diehl je bila prijateljica vodje SS-a Heinricha Himmlerja in je preko njega uspela urediti nekatere privilegije za Rascherja. Od maja 1939 je kot član ustanove Ahnenerbe raziskoval raka, od avgusta istega leta pa je bil zaposlen kot zdravnik pri nemškem letalstvu. Decembra 1940 je začel sodelovati z zdravniki iz taborišča Dachau, leta 1941 pa je dobil od Himmlerja dovoljenje, da na zapornikih izvede raziskave, povezane $\mathrm{z}$ višinskimi poleti, torej pri znižanem zračnem tlaku. Takoimenovani hipobarični poskusi so potekali v Dachauu od februarja do maja 1942. Sledili so poskusi s podhlajevanjem in drugi, ki so natančneje opisani v nadaljevanju. Karoline Diehl je dobila prvega otroka pri svojih 47 letih, nato pa še tri. Navzven sta z Rascherjem prikazovala, kot da jih je Karoline sama rodila, in o naraščaju sta tekoče obveščala Himmlerja. Leta 1944 pa se je izkazalo, da so bili vsi štirje otroci ugrabljeni kot dojenčki in nekateri celo naknadno zamenjani. Zato so Karoline Rascher odpeljali v taborišče Ravensbrück, kjer so jo usmrtili že leta 1944, Sigmunda Rascherja pa konec aprila 1945 v Dachauu. temperatura na različnih delih telesa, določali krvno sliko in podobno ${ }^{21}$. Potapljanju naj bi sledili poskusi, ki naj bi pokazali, kateri postopek ponovnega segrevanja je najboljši. Zapornike, moške, so potapljali oblečene ali gole, zavestne ali anestezirane, $\mathrm{v}$ bazene $\mathrm{s}$ hladno vodo $\left(2-12^{\circ} \mathrm{C}\right)$. Eksperimentalne podatke so $\mathrm{v}$ glavnem uničili, ostaja pa precej informacij, ki izhajajo iz korespondence med vodji poskusov in Heinrichom Himmlerjem, šefom SS-a. Takoj po vojni so podatke zbrali v obliki 228 strani dolgega poročilaxiII. Poskusov naj bi bilo med 360 in 400, na 280 do 300 ljudeh; 80-90 jih je zaradi teh poskusov umrlo. Glede na to poročilo kaže, da raziskava ni bila dovolj sistematična, da so zanemarili številne pomembne podatke za interpretacijo itd. $\mathrm{Z}$ medicinskega stališča so hipotermični poskusi, pa tudi večinsko odklonilen odnos stroke do vrednosti teh poskusov, bili obdelani leta $1990^{21}$.

Krajnc naj bi predvsem sodeloval v "pektinskih poskusih «, ki so bili namenjeni pripravi formulacije in testiranju preparata »Polygal-10« za strjevanje krvi. Poskusi s tem preparatom naj bi potekali v letih 1943 in $1944^{22}$.

Razvoj sredstva za strjevanje krvi je zadnji obsežnejši projekt Rascherjeve skupine $\mathrm{XXIV}^{\mathrm{X}}$ in je tekel sočasno $\mathrm{z}$ manj obsežnima poskusoma priprave krompirja $\mathrm{v}$ prahu oz. v tabletah ter sredstva proti rjavenju $\mathrm{z}$ manjšo vsebnostjo linolne kisline. Sredstvo za strjevanje krvi naj bi raziskovali od jeseni 1943, že decembra istega leta pa naj bi ga dali v uporabo dachauskemu zaporniškemu zdravniku dr. Kahru. Glede na to, da so Rascherja marca 1944, ob izbruhu afere, povezane $\mathrm{z}$ otroci, ki naj bi jih rodila njegova žena, $\mathrm{v}$ resnici pa so bili ugrabljeni, premestili $\mathrm{v}$ München, raziskav ni več mogel nadaljevati, njegov Oddelek R pa je s 1. majem 1944 prevzel dr. Kurt Plötner ${ }^{\mathrm{Xxv}}$.

XXIII Sestavil ga je avstrijsko-ameriški psihiater in nevrolog Leo Alexander (1905-1980), sicer glavni medicinski svetovalec sodišča pri Nürnberških procesih, med vojno pa v činu majorja sodelavec ameriške armade v Evropi.

XXIV Hubert Rehm v knjigi o Rascherju meni, da je bil projekt Polygal po zaključku poskusov s podhlajevanjem za Rascherjevo skupino najpomembnejši projekt in edini, ki je temeljil na lastni ideji, zato je bil pod pritiskom, da projekt uspe. To naj bi vplivalo tudi na interpretacijo rezultatov, če ne celo na izvedbo poskusov.

XXV Kurt Plötner (1905-1984) je leta 1930 zaključil študij kemije in leta 1934 opravil državni izpit iz medicine. Doktoriral je leta 1939 s področja serumskih proteinov in naslednje leto postal docent na univerzi v Leipzigu $^{40}$. Leta 1941 je delal kot vodja internističnega oddelka $\mathrm{v}$ bolnišnici vojnega letalstva $\mathrm{v}$ Dachauu, nato pa je leto in pol služboval v bolnišnici v zasedenem Minsku. Konec leta 1943 je prevzel mesto asistenta Klausa Schillinga pri poskusih, povezanih z malarijo, maja 1944 pa je postal vodja nekdanjega 'Oddelka R' Sigmunda Rascherja, ki se je ob tem preimenoval v 'Oddelek P'. Sočasno je bil na mestu taboriščnega zdravnika v Sachsenhausnu. Poleg preizkušanja sredstva za strjevanje krvi naj bi sodeloval pri preizkusih dveh nevarnih spojin na zapornikih: potencialnega bojnega strupa $\mathrm{z}$ delovnim imenom N-Stoff (klorov trifluorid) ${ }^{23}$ in psihoaktivne spojine 3,4,5-trimetoksifenetilamin (meskalin, po izvoru iz kaktusa pejotla). Pri meskalinu naj bi opazoval obnašanje poskusnih oseb; predvsem naj bi poskusil ugotoviti, če deluje kot 'serum resnice.' Leta 1945 naj bi v zvezi s temi poskusi začel sodelovati z ameriško Cio in prevzel priimek Schmitt, s čimer se je zavaroval pred aretacijo francoske uprave. Leta 1952 si je vrnil stari priimek in dobil zaposlitev na Freiburški univerzi, kjer je predaval v nazivu izrednega profesorja. 
Ta se je v veliki meri posvetil sredstvu za strjevanje krvi, ki ga je preimenoval v Styptoral. O nadaljevanju poskusov s podhladitvijo naj bi potekali pogovori, a jih najverjetneje niso izvajali ${ }^{24}$.

V osnovi naj bi preparat Polygal oz. Styptoral sestavljal ekstrakt sladkorne pese, a se je njegova sestava $\mathrm{v}$ procesu optimizacije spreminjala, saj je sprva bila surovina jabolčni pektin iz ostankov po stiskanju soka. Preventivno jemanje tega preparata naj bi zmanjšalo krvavitve, ki bi bile posledica bojevanja, pa tudi pri operacijah ali zaradi notranjih krvavitev pljuč ali prebavil. Na nekaterih taboriščnikih naj bi poskus opravili tako, da so jim dali preparat, nato pa amputirali zdravo okončino, ali jih ustrelili $\mathrm{v}$ vrat ali trup.

Idejo za preparat je Rascher dobil od dachauskega zapornika, avstrijskega kemika Roberta Feixa (18931973), ki je pred vojno razvil tekoče želirno sredstvo Opekta za uporabo v gospodinjstvih. Sodeloval je tudi pri njegovi proizvodnji v Kölnu. Za medicinsko uporabo pa naj bi pod Rascherjevim vodstvom razvili preparat $\mathrm{v}$ tabletah. Feix je najverjetneje vložil patentno prijavo za medicinski pektinski preparat že leta 1942, preden so ga zaprli in kasneje internirali v Dachau (tja je prispel konec januarja 1943), patent pa je bil odobren oktobra 1943.

Izkazalo se je, da je že v 30 -tih letih pektinski preparat za strjevanje krvi Sango-Stop ${ }^{\mathrm{xXVI}}$ proizvajalo neko nemško podjetje. Šlo je za tekočino za intramuskularno ali podkožno injiciranje. Tudi v Franciji so že pred tem uporabljali pektinske injekcije za zaustavljanje krvavitev ${ }^{25}$. Ideja o pektinskem preparatu torej ni bila nova, je pa prišla pobuda v pravem času, ko se je pokazala potreba po zaustavljanju krvavitev pri vojakih na frontni črti, pri čemer je bila dodana vrednost to, da bi preparat bil na voljo $\mathrm{v}$ obliki tablet.

Patent za Polygal je pri nemškem patentnem uradu v Berlinu datiran z 2. oktobrom 1943. Da je preparat praktično obstajal že jeseni 1943, in da so načrtovali njegovo proizvodnjo, dokazuje pisni dogovor oz. predpogodba (z dne 12. 10. 1943) med Rascherjem in Feixom ${ }^{26}$ glede proizvodnje in delitve dobička od prodaje preparata ${ }^{\text {xxvII }}$ S Se marca 1944 je Wolfram Sievers, predstojnik ustanove Ahnenerbe ${ }^{\mathrm{xxvIII}}$, predvideval zagon proizvodnje Polygala $\mathrm{v}$

XXVI Preparat Sango-Stop je na primer strokovno obravnavan v članku Georga Sacka ${ }^{29}$ iz leta 1935 z opisom zdravljenja treh primerov nenadne krvavitve pri hemofilikih. Uporaben naj bi bil tudi pri obolenjih prebavil, pri katerih pride tudi do driske. Opis preparata in doziranje sta opisana tudi v kratkem prispevku E. Gohrbandta ${ }^{30}$ iz leta 1936. Pod tem imenom ga je prodajalo podjetje Turon iz Frankfurta ${ }^{31}$.

XXVII Proizvodnja naj bi potekala v navezavi s podjetjem Sicabo na Predarlberškem, za prodajo pa bi ustanovili posebno podjetje. Feix naj bi imel proizvodne in prodajne pravice, ob tem pa bi mu pripadalo $5 \%$ prihodkov za čas trajanja patenta. Udeležba pri dobičku bi bila taka, da bi $33 \%$ pripadlo Rascherju, ravno toliko Feixu in 34 \% družbenikom. Enaka delitev bi veljala tudi pri šele načrtovanih patentih v tujini.

XXVIII Ahnenerbe je bila sprva organizacija za strokovno obravnavo arijske zgodovine. Ustanovili so jo leta 1935 in je delno delovala kot društvo, a je bila del SS-a. V njej je imel vsaj od leta 1937 glavno besedo vodja bližini Bodenskega jezera ob pomoči nekaterih privilegiranih zapornikov. Pristojni odbor pa je proizvodnjo zavrnil, češ da ta ni v pristojnosti raziskovalnih oddelkov, je pa odobril razvoj postopkov za proizvodnjo tega zdravila. Kasneje je proizvodni del projekta prevzelo podjetje Deutsche Heilmittel $^{24}$, a so bile priprave na proizvodnjo vezane na objekt v Schlachtersu, ki je bil podružnica (včasih imenovana tudi podružnica Biesings) taborišča Dachau, ustanovljena 4. aprila 1944 prav za zagon proizvodnje ${ }^{27}$. Za proizvodnjo so izbrali opuščeno sirarno, $v$ bližini pa je bil tudi objekt, nekakšen skedenj, ki so ga preuredili za nastanitev osebja, kasneje pa so najeli in preuredili za bivanje nekdanje kegljišče v vaški gostilni. Del proizvodnje naj bi potekal v tamkajšnji žganjarni Nikolodi, zadnji del sušenja pa v mlekarni Edelweiss. Delalo naj bi med 6 in 8 zapornikov, ki sta jih čuvala dva SS-ovca, a so se kljub prepovedi večkrat sprehajali po vasi in bili v občasnih stikih $\mathrm{z}$ domačini ${ }^{28}$. Kasneje so zaradi bližajočih se francoskih enot proizvodnjo preselili v nekdanjo pivovarno Reiner v kraju Lochau pri Bregenzu. Tam je bila izpostava taborišča Dachau že leta 1942, ko je v njej delovalo kovinsko podjetje s prisilnimi delavci in ujetniki. Isto poslopje so usposobili za delovanje in uradno odprli kot enoto za proizvodnjo pektinskega preparata 7. aprila 1945, delavci pa bi bili zaporniki in sodelavci (nekdanje) skupine Sigmunda Rascherja oziroma Kurta Plötnerja. Tam naj bi delalo med 5 in 20 zapornikov iz Nemčije, Poljske in Slovenije, varovalo pa jih je 5 starejših SS-ovcev ${ }^{32}$. Koliko tablet so izdelali, ni jasno, obstajajo pa podatki, da so preparat preizkušali na več klinikah.

Kljub temu, da je osnovna formulacija preparata bila znana že jeseni 1943, so potekale raziskave v smeri optimizacije sestave in postopka priprave še $\mathrm{v}$ jeseni 1944. Pri iskanju podatkov o drugih kemikih, obsojenih na dachauskih procesih, sem dobil kopijo laboratorijskih zapiskov ${ }^{\text {XxIx }}$ iz Dachaua, ki predstavljajo dober vpogled v raziskave, opravljene poleti in jeseni leta 1944. Avtor teh zapiskov je bil po vsej verjetnosti Milan Stepišnik, ki je delal v Plötnerjevi skupini skupaj s Krajncem. Natančnejši prikaz vsebine teh zapiskov bo tema enega od kasnejših člankov, saj gre za prvi verodostojen opis postopkov priprave pektinskega preparata v Dachauu, kot tudi za pregled rezultatov testiranj na zapornikih.

SS-a, Heinrich Himmler, ki je praktične zadeve vodil preko generalnega tajnika Wolframa Sieversa. Ta je tudi vodil Inštitut za namenske vojaškoznanstvene raziskave, ki je bil ustanovljen julija 1942. Večino psevdomedicinskih raziskav je Rascherjeva skupina opravila v okviru tega inštituta, ki je omogočal tudi zaposlitve nekdanjih taboriščnikov.

XXIX V lasti družine Stepišnik je rokopisni zvezek, ki predstavlja zanimiv in dragocen dokument o raziskovalnem delu v skupini Kurta Plötnerja, ki pa je logično nadaljevanje prvotnih raziskav iz obdobja, ko je skupino vodil Sigmund Rascher. Na osnovi rokopisa je mogoče reči, da zvezka ni pisal Krajnc, pač pa bolj verjetno Stepišnik. Da je Stepišnik iz taborišča prinesel zapiske, je navedla njegova žena v pismu slovenskemu izvršnemu svetu, ko se je zavzemala za rehabilitacijo obsojenih. Tam je tudi zapisala, da so bili zapiski zaplenjeni ob hišni preiskavi, zato ni jasno, kako so se ponovno znašli v lasti Stepišnikovih. 
V zvezku so navedeni osnovni pristopi k pripravi ekstrakta iz rezin sladkorne pese, kar je vključevalo kislo hidrolizo pektina in kasnejše umiljenje $\mathrm{z}$ dodatkom $\mathrm{NaOH}$. V nadaljevanju je predstavljen del raziskav o vlogi morebitnih dodatkov, ki bi lahko čas strjevanja krvi še skrajšali, med drugim različne kisline biološkega izvora. Pri ovrednotenju učinkovitosti so izvajali tudi teste na ljudeh. Nekateri so dobili preprat oralno, drugi intravenozno, tretji intramuskularno. Čas strjevanja krvi so določali v rednih časovnih intervalih, običajno do $7 \mathrm{~h}$ po doziranju preparata oz. dodatka. Kri so jemali iz žile (venska) in iz uhlja (kapilarna), čas strjevanja pa so določali na vbodni rani na uhlju. Ena serija poskusov je bila namenjena spremljanju hitrosti strjevanja krvi v odvisnosti od vremena, tako da so na treh ljudeh izvajali meritve vsak dan skozi več kot en mesec in vzporedno beležili vremenske podatke. Preizkusne osebe so navedene $\mathrm{z}$ začetnicami imena in priimka, starostjo, telesno težo in višino. Zadnji poskusi, opisani $\mathrm{v}$ zvezku, so od 11. oktobra 1944. Kot vemo, je Krajnc pobegnil iz ujetništva v začetku novembra 1944, pa tudi Stepišnik naj bi ostal v Dachauu samo do konca oktobra. Zato je bilo sprva težko reči, kdo je bil avtor zvezka ${ }^{\mathrm{xxx}}$. Na osnovi primerjave rokopisa s Krajnčevim iz arhivskega gradiva Univerze v Ljubljani ${ }^{\mathrm{XxXI}}$ in Arhiva RS je mogoče reči, da avtor teh zapiskov ni Krajnc. Zapiski so v slovenščini, torej je avtor moral biti Slovenec. Glede na veliko število preizkušancev (okrog 80), se zdi najbolj verjetno, da so meritve opravili v taborišču Dachau in ne v podružnici Schlachters, kjer naj bi bilo vsega skupaj manj kot 10 ljudi. Od Slovencev so bili v Rascherjevi skupini Krajnc, Stepišnik, Barle (vsi kemiki) ter Ravnikar (krojač) in Pufler (steklar). Barle je bil od poletja $1944 \mathrm{v}$ Schlachtersu, zato ni mogel sodelovati pri izvedbi opisanih poskusov. Zato je utemeljeno sklepati, da gre za Stepišnikov zvezek. Glede znanstvene vrednosti zbranih meritev velja pripomniti, da so $\mathrm{v}$ veliki večini teste izvajali $z$ istim preparatom na samo enem človeku, kar je $\mathrm{z}$ današnjega stališča nesprejemljivo.

Naknadno sem v Krajnčevem dosjeju v Arhivu RS odkril tipkopis, ki vključuje večino tistih poskusov, ki so opisani v Stepišnikovih zapiskih, pa tudi nekaj dodatnih. Pri pisanju je bil uporabljen pisalni stroj s slovenskimi znaki, zato je verjetno, da gre za prepis rezultatov, ki jih je Krajnc ob pobegu prinesel iz Dachaua, a so bili takrat rokopisni. Vsebina omenjenega tipkopisa bo predmet kas-

\footnotetext{
XXX Zapiske Borisa Krajnca je omenjala njegova žena v pogovoru za časopis Dnevnik. Po mnenju Ivanke Krajnc naj bi njen mož zvezek s podatki iz Dachaua odnesel na fakulteto, kjer se je zaposlil in nadaljeval delo na pektinskih preparatih, vendar zvezka na fakulteti ne hranijo. V knjigi Bore Krivokapića ${ }^{33}$ je v delu, ki opisuje njegov pogovor z Ivanko Krajnc in njeno borbo za razjasnitev okoliščin, povezanih s smrtno obsodbo njenega moža, zapisano, da je Boris Krajnc med poskusi v Dachauu vodil tajne zapiske, ki jih je ob pobegu iz taborišča prinesel s seboj. Nekaj naj bi jih zasegli med hišno preiskavo, nekaj pa jih je v času, ko je podala izjavo, še hranila.
}

XXXI Arhiv hrani vpisni list v 1 . semester študija (september 1933). Primerjal sem značilen način pisanja pisanih črk $B, K, S, p, r$ in $z$, ki so drugačne kot v zvezku s podatki iz Dachaua. nejše analize, ki bo predstavila tudi Stepišnikove zapiske (članek v pripravi).

\section{Boris Krajnc v gradivih, povezanih s taboriščem Dachau}

V Arolsenskem arhivu (International tracking service, Bad Arolsen, Nemčija) hranijo malo gradiva o Krajncu. Iz taboriščnega vpisnega lista za B. Krajnca je razvidno, da je bil Krajnc pripeljan v taborišče Dachau 18. marca 1942 in izpuščen 22.12.1943. Tik pred izpustitvijo, 10.12., naj bi bil ,prepeljan in 16.12.,vrnjen', a iz arhiva ni jasno kje bi bil $\mathrm{v}$ vmesnem času. Možno je, da gre za obdobje, ko naj bi ga premestili v Berlin, o čemer je več napisanega v nadaljevanju. Kategorija zapora je bila Schutzhäftling, torej varnostni pripornik, kar je pomenilo zapor brez sojenja in brez določenega trajanja zapora. To je bil pogost način odstranitve politično neprimernih ljudi.

Kot je razvidno iz naloga za oddajo telegrama, ki ga hrani Arolsenski arhiv, razvidno pa je tudi iz zapisnika sojenja v Nürnbergu (2. 1. 1947) je 10. 12. 1943 Rascher pisal svojemu nadrejenemu v ustanovi Ahnenerbe (slika 3) glede Borisa Krajnca, za katerega je zvedel, da naj bi ga izpustili v skladu $\mathrm{z}$ odločitvijo od 19.11. 1943 in ga premestili $v$ nemški glavni varnostni urad v Berlinu ${ }^{\text {xxxII. }}$. Sicer da podpira njegovo izpustitev, a nujno prosi, da bi Krajnc ostal pri njem, kajti je sredi dela, ki ga je naročil načelnik SS, Krajnc pa je Rascherjev najboljši kemik, ki zna delo opraviti strokovno in korektno. $\mathrm{V}$ nasprotnem teoretičnega dela raziskave na poligalu ne bo mogoče dokončati, saj je Krajnc njegov edini organski kemik ${ }^{34}$.

Ostalo gradivo v Arolsenskem arhivu ne razkriva Krajnčeve vloge $\mathrm{v}$ (psevdo)medicinskih poskusih. Izrecno je omenjen kot kemik samo pri poskusih strjevanja krvi in sicer $\mathrm{v}$ zbirnem poročilu ${ }^{35}$, pripravljenem po vojni na osnovi primarnih virov, predvsem korespondence dr. Rascherja in delovnega poročila o preparatu. Arolsenska arhivska služba ni našla podatkov o tem, da bi Krajnc sodeloval pri drugih poskusih v Dachauu.

Gradiva o Krajncu je v Arolsenskem arhivu leta 1970 preverjalo javno tožilstvo pri deželnem sodišču München II v povezavi s preiskavo proti nekdanjim članom SS, ki so sodelovali pri medicinskih poskusih $\mathrm{v}$ koncentracijskem taborišču Dachau. Iskali so morebitne priče poskusov, predvsem preživele poskusne osebe, pa tudi morebitne sodelavce pri poskusih. Med temi so iskali tudi podatke o

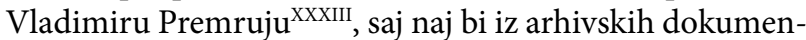

XXXII V zapisniku je navedena oznaka urada RSHA LV C 2, a gre verjetno za napako in bi namesto LV moralo pisati IV, kar bi pomenilo Urad IV, to je bil protiobveščevalni urad, oddelek za kartoteke, pisarna za taboriščne zadeve. Urad LV ni obstajal. V Rehmovi knjigi o Rascherju je naveden urad IVC2.

XXXIII Več o Premruju je navedenega v nadaljevanju, ob obravnavi ostalih slovenskih kemikov, ki so sodelovali pri poskusih v nemških taboriščih. 


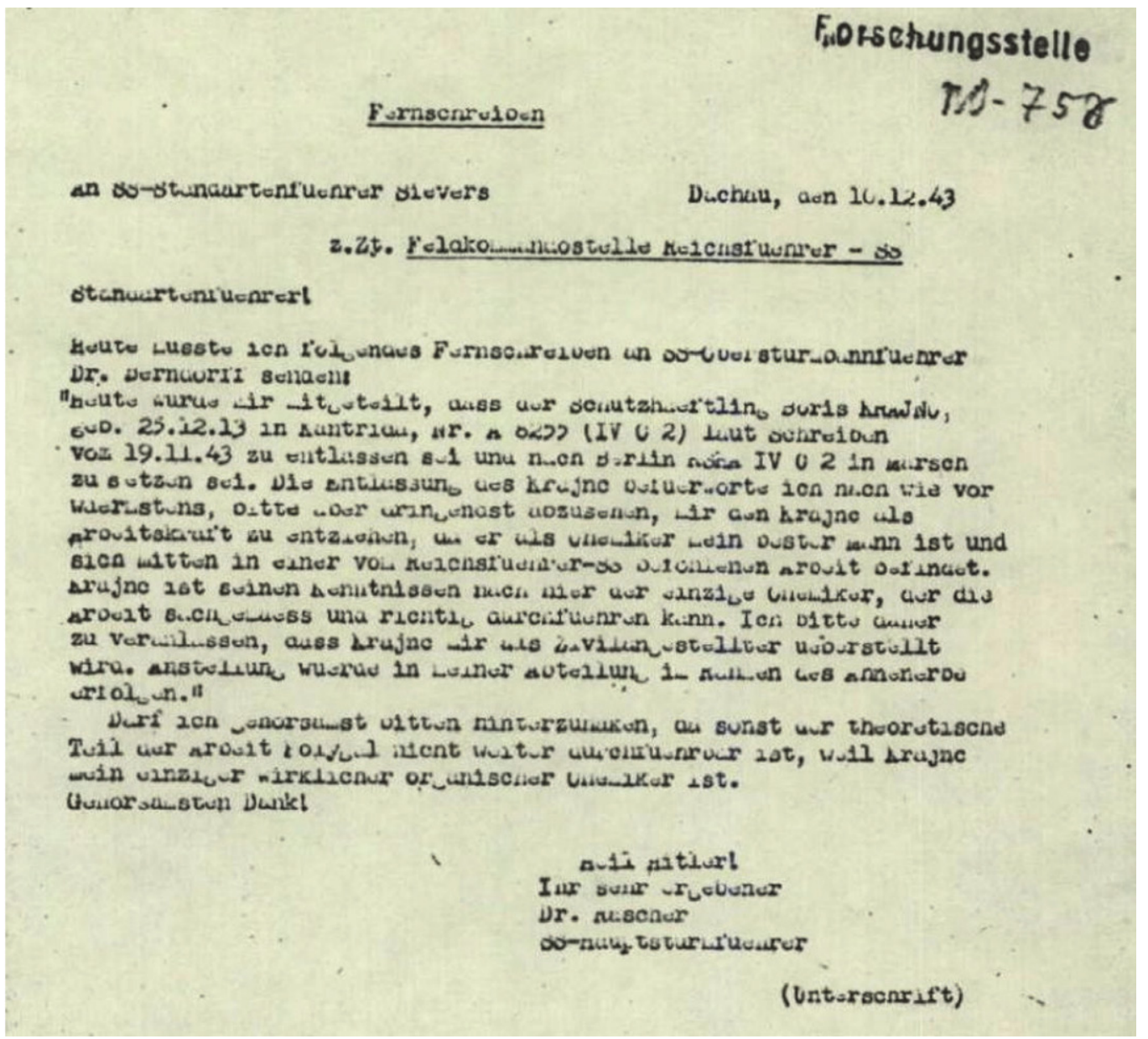

Slika 3: Dopis S. Rascherja vodji organizacije Ahnenerbe, dr. Sieversu. V telegramu, ki je bil tudi del dokaznega gradiva proti Sieversu na Nürnberškem procesu, Rascher prosi, da bi Krajnca po odpustu iz varnostnega pripora zaposlil kot kemika v okviru raziskovalne skupine, ki jo je Rascher vodil. V ključnem delu dopisa pravi: »Krajnčevo izpustitev še naprej najtopleje zagovarjam, vseeno pa najnujneje prosim, da se odpoveste temu, da bi Krajnc zapustil delovno mesto pri meni, ker je kot kemik moj najboljši mož in sredi dela, ki ga je ukazal državni vodja SS-a. Krajnc je po svojih znanjih tu edini kemik, ki zna opraviti delo strokovno in natančno. Zato prosim, da poskrbite, da bi Krajnca premestili k meni kot civilnega uslužbenca. Zaposlitev bi bila na mojem oddelku v okviru Ahnenerbe. Dovolite, da najpokorneje prosim, da se zavzamete za to zadevo, sicer teoretični del projekta Polygal ne bi bil več izvedliv, saj je Krajnc moj edini pravi organski kemik. "Vir: Digitalni arhiv ITS, Bad Arolsen, št. dokumenta 4.2 / 82231970.

tov javni tožilec ugotovil, da je bil marca 1944 dodeljen skupini dr. Rascherja.

V zborniku o taborišču Dachau je v poglavju o jugoslovanskih komunistih ${ }^{36}$ navedeno, da naj bi Krajnc konec maja 1944 (očitno ob odhodu na dopust) v Slovenijo v tubi zobne paste pretihotapil poročilo slovenskih komunistov o stanju v taborišču. Poročilo sta napisala Bogdan Švent in Jože Zakovšek, namenjeno pa je bilo Rudiju Janhubixxxiv, ki je bil takrat v Beli Krajini. Pri posredovanju poročila Krajncu je sodeloval Branko Diehl.

O Sigmundu Rascherju je leta 2006 izšel roman z naslovom »Der Untergang des Hauses Rascher» (Konec

XXXIV Rudi Janhuba (1914-1976) je bil španski borec, ki je po porazu republikancev bil interniran v Franciji, nato pa je bil na prisilnem delu v Nemčiji, od koder je leta 1941 ušel in se pridružil partizanom, kjer je dosegel čin podpolkovnika. Bil je delegat centralnega komiteja Komunistične partije Slovenije pri organiziranju partizanov na Štajerskem in Koroškem, nato pa je deloval v varnostno-obveščevalni službi v Ljublja$\mathrm{ni}^{37}$. Po vojni je deloval kot časnikar in diplomat. Med špansko državljansko vojno je nekaj časa deloval v mestu Albaceta, tako kot Branko Diehl.
Rascherjeve hiš $\mathrm{exxv}^{\mathrm{xxv}}$, ki v največji meri temelji na zgodovinskih gradivih. Ta so v romanu tudi citirana. Avtor romana je Hubert Rehm ${ }^{\mathrm{xxxvI}}$, a je pri tem delu uporabil psevdonim Siegfried Bär. V tem dokumentarnem romanu se Krajnc pojavlja na več mestih, a roman ne daje natančnejšega vpogleda $v$ njegovo delo. Več je napisanega o drugem Rascherjevem sodelavcu iz današnje Slovenije,

XXXV Kot navaja avtor v 5. izdaji $(2020)^{25}$, je naslov parafraziran po zgodbi Edgarja Allana Poeja The Fall of the House of Usher, v nemškem prevodu Der Untergang des Hauses Usher. Zgodba govori o R. Usherju, kar se izgovori podobno kot Rascher. V slovenščini so prevodi za Poejevo delo različni, zadnji prevod Jožeta Udoviča pa ima naslov Konec Usherjeve hiše, zato sem temu ustrezno prevedel tudi naslov Rehmovega romana.

XXXVI Hubert Rehm (roj. 1951) je leta 1983 doktoriral iz biokemije in je nato deloval kot raziskovalec, a se je kasneje posvetil pisanju in založniškemu delu. Je soizdajatelj nemške strokovne revije Laborjournal in je avtor ali soavtor več učbenikov oz. laboratorijskih priročnikov s področja biokemije. Piše tudi satirično prozo, npr. o tem, kako postati univerzitetni profesor, in kritična dela o financiranju raziskovalnega dela v Nemčiji. Roman o dr. Rascherju je doživel že 5. izdajo in je bil preveden tudi v angleščino. 
Rudiju Punzengruberju ${ }^{\mathrm{xxxvII}}$. Krajnc je obširneje omenjen predvsem v kontekstu njegove premestitve iz statusa zapornika v sodelavca, zaposlenega preko ustanove Ahnenerbe, decembra $1943^{\mathrm{xxxvIII}}$. Nadalje je navedeno, da je oktobra 1944 pobegnil iz Schlachtersa, vse nadalinje omembe pa so povezane s sojenjem v Ljubljani. Schlachters je ime kraja, kjer je Rascher organiziral proizvodnjo preparata Polygal in je bil uradno delovna podružnica taborišča Dachau. Šlo je za zakup mlekarne, ki je bil pravno urejen konec marca 1944, takrat že brez Rascherja. Tam je najprej delalo okrog 5 zapornikov, kasneje pa verjetno nekaj več.

Poleg Krajnca (in Punzengruberja, ki pa se ni imel za Slovenca), Rehmova knjiga od slovenskih kemikov omenja samo še Vladimirja Premruja, ki naj bi ga Rascher vključil $\mathrm{v}$ delo svoje skupine po tem, ko je od Punzengruberjeve mame Dore zvedel, da je zaprt v Dachauu.

Slovenski kemiki so omenjeni tudi v knjigi Julijana Reitzensteina o raziskavah pod Himmlerjevim okriljem in $\mathrm{v}$ okviru ustanove Ahnenerbe ${ }^{40}$. Na seznamu ,kdo je kdo na Inštitutu za namenske vojaškoznanstvene raziskave (priloga v knjigi) so omenjeni Krajnc (zapisano napačno: Krajic in brez akademskega naziva, zgolj kot sodelavec-zapornik), Punzengruber in Stepišnik (zapisano napačno: Stepinski).

Uradni nemški in zavezniški viri iz povojnega obdobja ne vsebujejo podatkov o tehničnem osebju, ki je delalo v Rascherjevi skupini.

XXXVII Rudolf Emanuel Punzengruber je bil rojen leta 1900 v Črni na Koroškem (Schwarzenbach). Kot navaja Rehm ${ }^{25}$, je na graški univerzi študiral kemijo in tam doktoriral decembra $1925 \mathrm{z}$ disertacijo o alkalni hidrolizi etilestrov ocetne kisline $s$ karbonati enovalentnih kationov $\mathrm{Li}^{+}$, $\mathrm{Na}^{+}$in $\mathrm{Rb}^{+}$. Doma so imeli kmetijo, žago in trgovino. Bili so pronemško usmerjeni in so podpirali nacionalsocializem, čeprav je bila njegova mama Slovenka. Med obema vojnama se je zapletel v finančne škandale, ob izbruhu vojne pa je bil verjetno zaposlen pri kraljevi vojski v Beogradu, kjer je bil prijavljen v hotelu Astoria. Maja 1941 so ga priprli in v preiskovalnem zaporu je ostal do konca junija 1942, ko so ga premestili $\mathrm{v}$ taborišče Dachau. S posredovanjem Rascherjevega sodelavca Neffa je prišel v raziskovalno skupino dr. Rascherja, kjer je sodeloval pri poskusih podhlajevanja, vzporedno pa je razvijal zaščitni premaz proti rji. Postal je nekakšen vodja kemikov in pod njegovim vodstvom jih je delalo $5^{72}$, med njimi Krajnc. Punzengruber je dajal videz premožnega človeka, čeprav to ni bil. Z Rascherjem sta se dobro razumela, tako da je Rascher septembra 1943 preživel dopust v Mežiški dolini. Istega meseca je bil Punzengruber izpuščen iz taborišča, a je nadaljeval delo $\mathrm{v}$ Rascherjevi skupini, čeprav je bil formalno dodeljen policiji kot rezervist, zato ga niso vpoklicali na fronto. Marca 1944 se je izkazalo, da sredstvo proti rji še ni primerno za proizvodnjo, zato so nadaljevali z njegovo optimizacijo, a neuspešno, tako da so julija 1944 umaknili patentno prijavo zanj. Oktobra 1945 se je Punzengruber poročil s Giso Schäfer, roj. Wagner, tehničarko na univerzitetni kliniki v Münchnu, kamor je prej prinašal vzorce v analizo. Po vojni so Američani Punzenguberja aretirali in najprej zaprli v Dachauu, nato pa preselili v zaporniško krilo sodišča $\mathrm{v}$ Nürnbergu. Pričal je proti Rascherju in na vsak način poskusil zmanjšati svojo vlogo v Rascherjevi skupini ${ }^{38,39}$. Iz neznanega razloga je $\mathrm{v}$ ameriških sodnih virih naveden kot zdravnik (tako je omenjen tudi v knjigi nekdanjega bolničarja v Dacahuu, zgodovinarja Stanislava Zamečnika Das war Dachau). Kasneje se je podpisoval tudi kot Rolf Punzengruber. Do leta 1966 je živel v Münchnu, kjer je tudi pokopan.

XXXVIII Krajnčeva mesečna plača je bila 385 mark $^{40}$.
V Arolsenskem arhivu hranijo kopijo dokumenta od 11. januarja 1944, ki so ga iz taborišča poslali na policijsko upravo (verjetno mesta Dachau), v njem pa je navedeno, da je bil Boris Krajnc $\mathrm{z}$ dnem 22. 12. 1943 izpuščen iz zapora in sočasno sprejet $\mathrm{v}$ delovno razmerje $\mathrm{v}$ Uradu $\mathrm{A}^{\mathrm{xxxIx}}$ Personalnega štaba SS-a - to je bil urad, pod katerega je sodil Rascherjev oddelek v okviru Inštituta za namenske vojaškoznanstvene raziskave. Policijsko upravo prosijo, da Krajncu izročijo ustrezne papirje, med drugim tudi karte za hrano in oblačila. Da je šlo za delovno razmerje, potrjuje tudi seznam tujcev ${ }^{\mathrm{xL}}$, ki so med vojno bivali na področju kasnejše ameriške zasedbene cone in so ga lokalne oblasti kmalu po vojni pripravile za zavezniške sile $\mathrm{z}$ namenom razjasnitve usode tujcev. $\mathrm{Na}$ tem seznamu ${ }^{\mathrm{XLI}}$ je navedeno, da je bil Krajnc 26. 3. 1944 zaveden v kartoteki Urada za delo München, izpostava Dachau. Kot je razvidno iz po vojni pripravljenega seznama prebivalcev občine Dachau $^{\text {XLII }}$, je bil Krajnc tam prijavljen od 22. 12. 1943, za dopust konec maja 1944 pa se je začasno odjavil.

Zanesljivih dokumentov o njegovem bivanju v obdobju od junija do novembra 1944, ko naj bi se vrnil na Jesenice $^{\mathrm{XLIII}}$, sprva ni bilo mogoče najti. Možno bi bilo, da je po vrnitvi $z$ dopusta živel in delal v Schlachtersu kjer so $\mathrm{v}$ tistem času pripravljali obrat za proizvodnjo tablet Polygal. Prav tako maja 1944 naj bi v Schlachters iz Dachaua bil premeščen Janko Ravnikar, še en Slovenec iz Rascherjeve skupine, kjer je sodeloval kot pomožni delavec, po poklicu pa je bil krojač. V Rehmovem dokumentarnem romanu je

XXXIX Od leta 1940 naprej je pod to oznako treba razumeti SS-ovo organizacijo Ahnenerbe.

$\mathrm{XL} V$ povojnem času so zavezniške zasedbene sile sistematično zbirale podatke o dogajanju v Nemčiji med 2. svetovno vojno, odkriti pa so želeli tudi usodo številnih zapornikov, prisilnih delavcev in drugih, ki so jih nemški okupatorji prepeljali v Nemčijo. Tako so med drugim morali lokalni uradi sestaviti popise vseh tujcev, ki so med vojno bivali v Nemčiji in sezname zaposlenih tujcev v nemških podjetjih.

XLI Seznam jugoslovanskih delavcev, ki ga je pripravil Urad za delo iz Münchna, str. 3 seznama izpostave Dachau, interna oznaka strani ITS 074. Na istem seznamu (str. 6 oz. ITS 077) je tudi Milan Stepišnik (več o njem v nadaljevanju) $\mathrm{z}$ datumom evidentiranja 15. 9. 1944. Gre za takoimenovani Formular 11.

XLII Na seznamu tujcev 'jugoslovanske narodnosti', ki so ga pripravili na občini Dachau avgusta 1946, je Boris Krajnc vpisan s priimkom Kraync. Prebivališče (Formular 7; stran ITS 090) je prijavil z datumom 22. 12. 1943 in datumom odjave 24. 5. 1944. Na formularju za popis dokumentov (Formular 10, stran ITS 224) pa je navedeno, da je bila personalna mapa za zaposlitev odprta 14. 1. 1944. Kartotečna kartica navaja naslednje podatke: Kraync Boris, dipl. inž. kemije, rojen 25. 12. $1913 \mathrm{v}$ Kantridi (prej Italija, zdaj nemško), vera rk (rimskokatoliška), priselitev iz KL (koncentracijskega taborišča) Dachau 22. 12. 1943, odselitev 24. 5. 1944 v Cilli (Celje), ponovna priselitev 6. 6. 1944 iz Cilli; državljanstvo: nekdanja Jugoslavija, narodna pripadnost: Slovenija. Stepišnik je v isti evidenci zaveden z datumom prijave 21. 7. 1944 (prihod iz koncentracijskega taborišča Dachau) in odjave 1. 11. 1944. Na evidenčni kartici je navedeno, da se je odselil v Aßling/Oberkrain (Jesenice na Gorenjskem).

XLIII Po mnenju Huberta Rehma naj bi Krajnc pobegnil iz Schlachtersa oktobra 1944, vendar je po naknadnem preverjanju (osebna komunikacija) ugotovil, da ni nobenega zanesljivega podatka o tem, da je res bil del ekipe za pripravo preparata Polygal v Schlachtersu. 
navedeno, da je Krajnc pobegnil domov iz Schlachtersa oktobra 1944, čeprav je iz povojnih slovenskih virov, predvsem številnih zaslišanj, mogoče ugotoviti, da se je vrnil na Jesenice novembra tega leta. Iz zapisnikov preiskovalnega postopka pred dachauskim procesom je razvidno, da je Krajnc pobegnil iz Dachaua na osnovi ponarejenega dokumenta, ki ga je z Jesenic prinesel Milan Stepišnik, zato je podatek o pobegu iz Schlachtersa dvomljiv. Prav tako je v romanu navedeno, da naj bi bil Krajnc španski borec. Res se pojavlja $\mathrm{v}$ nekaterih knjigah o mednarodnih brigadah $\mathrm{v}$ španski državljanski vojnix ${ }^{\text {XIIV }}$, ni pa ga na seznamih, ki so jih sestavili jugoslovanski prostovoljci v tej vojni.

\section{Krajnc kot obdolženec na Diehl-Oswaldovem procesu}

V preiskavi, ki ji je sledil prvi dachauski proces $\mathrm{v}$ Ljubljani, je bil Krajnc aretiran 27. 10. 1947 (podatek iz obtožnice vojaškega sodišča od 16. 4. 1948). Ohranjen je zapi- snik hišne preiskave na dan aretacije. Trajala je eno uro, $\mathrm{v}$ njej pa so zasegli med drugim dve mapi korespondence in dve mapi strokovnega gradiva.

Obtožnica je Krajnca bremenila, da je februarja 1942 $\mathrm{v}$ begunjskih zaporih prostovoljno začel sodelovati z Gestapom in mu priznal svoje sodelovanje $\mathrm{z}$ Osvobodilno fronto ter s tem izpostavil svoje sodelavce; da se je v Dachauu marca 1942 povezal $\mathrm{z}$ agentom Martinom Presterlom, mu poročal o sointernirancih in sodeloval $\mathrm{v}$ lažni protifašistični provokatorski organizaciji; da je od januarja 1943 do novembra $1944 \mathrm{v}$ poizkusni postaji aktivno sodeloval s krvnikoma Rascherjem in Plötnerjem pri najgrozovitejših zločinih; da je kot agent Gestapa posredoval pri vodstvu taborišča, da so bili na poizkusne postaje pritegnjeni še Stepišnik, Barle, Ličen in drugi, s čimer je soodgovoren tudi za njihove zločine. Obtožen je bil tudi oddaje lažne biografije, da bi se po vojni vrinil na vplivno mesto, od koder bi črpal tajne podatke kot bivši gestapovski agent in da bi protežiral gestapovske agente s pisanjem pozitivnih karakteristik. Nadalje je bil obtožen za povezavo s tujo obveščevalno službo

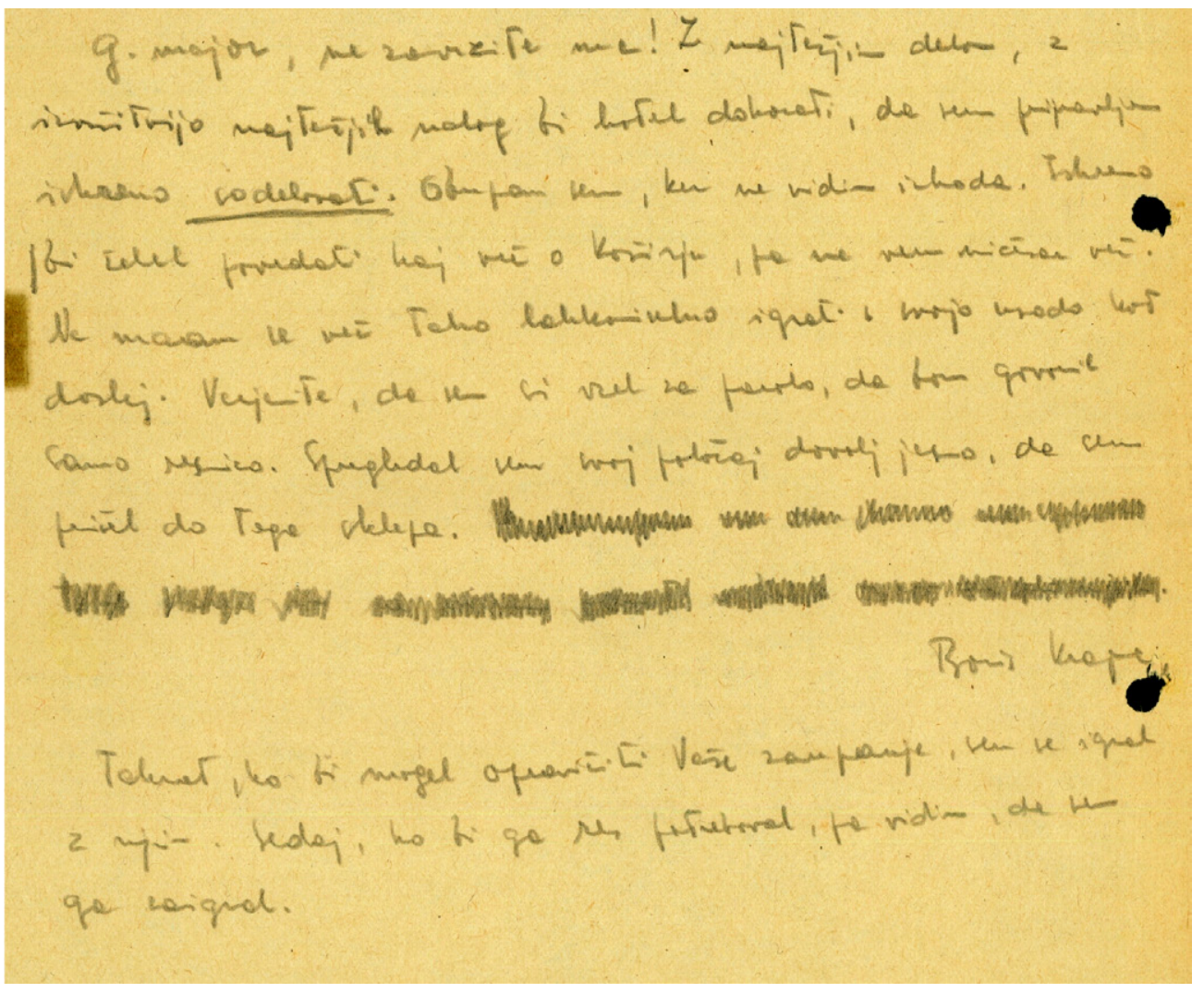

Slika 4: Rokopisna izjava Borisa Krajnca iz časa preiskave za Diehl-Oswaldov proces. Dokument ni datiran, verjetno pa sodi v obdobje malo pred sojenjem aprila 1948. Vir: Arhiv Republike Slovenija, SI AS 1931, RSNZ SRS, Dachauski procesi, šk. 512.

XLIV Krajnc je naveden $\mathrm{v}$ knjigi Las brigadas internacionales de la guerra de España (Andreu Castells, Esplugues de Llobregat: Editorial Ariel, 1974), vendar le kot soobtoženi na dachauskem procesu, kjer so sodili tudi številnim španskim borcem. Edina zgolj teoretična možnost, da bi kakor koli sodeloval pri zadevah, povezanih s špansko državljansko vojno, bi bila v času študija, saj so mednarodne brigade razpustili septembra 1938. junija 1945 ter da ji je poročal o dogajanju na univerzi in da je izvajal škodliive aktivnosti po navodilu tuje obveščevalne službe. Obtožnica je bila vložena 2. 12. 1947.

V knjigi o dachauskih procesih ${ }^{33}$ je Boro Krivokapić citiral pritožbo Krajnčeve žene Ivanke Komisiji za prošnje in pritožbe Centralnega komiteja Zveze komunistov Slove- 
nije $\mathrm{z}$ dne 12. 4. 1969. $\mathrm{V}$ tem dolgem pismu je navedeno, da je pod Krajnčevim mentorstvom opravljala diplomsko nalogo Jelka Ružičxiv, takrat svakinja, kasneje pa druga žena ${ }^{\mathrm{XLVI}}$ Borisa Kraigherja (v času sojenja je bil minister za notranje zadeve LR Slovenije). S posredovanjem Jelke Ružič je Krajnčevi uspelo priti na zasebni obisk k Borisu Kraigherju, ki ji je povedal, da bo Boris Krajnc nekaj časa zaprt in da se je to zgodilo na zahtevo tuje velesile. Nekateri menijo, da je šlo za Sovjetsko zvezo, neposrednih dokazov za to pa ni.

Sojenje pred vojaškim sodiščem ${ }^{\mathrm{XLVII}}$ je potekalo med 20. in 24. aprilom 1948, razglasitev sodbe pa je bila dva dni kasneje. To je bil prvi izmed dachauskih procesov in hkrati največji. Pogosto ga poimenujejo po dveh prvoobtoženih Diehl-Oswaldov proces. Danes velja, da je šlo za montiran proces, pri katerem so obdolžence s fizičnim in psihičnim nasiljem prisilili v priznanje dejanj, ki jih niso zagrešili. Nazoren prikaz postopkov, ki so jih uporabljali v zasliševanjih, je pričevanje Vlasta Kopača ${ }^{41}$, ki je bil na Diehl-Oswaldovem procesu obsojen na smrt, a so mu po pritožbi omilili kazen na 20 let zapora, nato pomilostili na 10 let in ,začasno izpustili aprila 1951. Na sojenju je bil pogosto edini dokaz za očitano dejanje lastno priznanje obdolženca, obramba, ki je bila imenovana, pa ni imela vpogleda v obtožnico in je bila pod pritiskom oblasti. Redkih dokazov v prid obdolžencem sodišče ni upoštevalo, večinoma pa odvetnikom niso dovolili povabiti prič, ki bi koristile obdolžencem. Na tem nepoštenem sojenju so izrekli izredno visoke kazni, saj so od 14 obdolžencev kar enajstim izrekli smrtno kazen. Upoštevati pa je treba še tri preiskovance, ki so umrli med preiskavo.

Krajnc je med zaslišanji priznal sodelovanje z Gestapom, ki naj bi ga podpisal v zaporu v Begunjah, in še nekatera druga očitana dejanja, vendar teh izjav ni mogoče šteti za verodostojne. Pod kakšnim pritiskom so bili preiskovanci, je mogoče razbrati iz Krajnčevega pisma majorju (verjetno preiskovalcu), ki ga hrani Arhiv Republike Slovenije (slika 4). Pri uporabi gradiv iz časa preiskave in $s$ sojenja je potrebna posebna previdnost, podobno kot velja tudi pri arhivskih dokumentih tajnih služb ${ }^{42}$.

\section{Drugi kemiki na dachauskih procesih}

Milan Stepišnik (1910-1950?) je bil tako kot Krajnc kemik (diplomiral 1935, tri leta pred Krajncem) in je bil obsojen na istem dachauskem procesu kot Krajnc. Stepišnik je diplomiral na Tehniški fakulteti z nalogo »Analogi-

\footnotetext{
XLV Jelka Marija Ružič je diplomirala šele leta 1949, torej več kot eno leto po Krajnčevi aretaciji.

XLVI Boris Kraigher je bil najprej poročen s sestro Jelke Ružič, arhitektko Miro Ružičc ${ }^{71}$.

XLVII Samo prvi dachauski proces je potekal pred vojaškim, vsi naslednji pa pred civilnim sodiščem.
}

ja med nikotinsko in m-nitrobenzojevo kislino « pod mentorstvom Marija Rebka. Znan je bil tudi kot vrhunski atlet. Med drugim se je udeležil olimpijskih iger v Berlinu leta 1936, kjer je bil zastavonoša jugoslovanske reprezentance, bil pa je tudi večkratni balkanski prvak ${ }^{\mathrm{XIVIII}}$. Znana je fotografija treh prvouvrščenih atletov na tekmovanju $\mathrm{v}$ jeseni $1941^{\text {XLIX }}$, kjer na zmagovalnem odru prvi in tretji pozdravljata s fašističnim pozdravom, Stepišnik kot drugi pa stoji mirno.

Do začetka vojne je bil zaposlen v tovarni Zogmeier-Gruber v Slovenski Bistrici, nato pa je bil do junija zaprt v Mariboru, čemur je sledila izselitev v Lazarevac v Srbiji. Od tam se je kmalu vrnil, saj so mu odobrili preselitev v Ljubljansko pokrajino, tako da je že 2. julija 1941 prišel v Ljubljano in se avgusta zaposlil v papirnici v Vevčah. Zaradi sodelovanja $z$ Osvobodilno fronto so ga novembra 1943 belogardisti ${ }^{\mathrm{L}}$ aretirali, kasneje pa so ga internirali v Dachau. V ameriški bazi Holocaust Survivors and Victims Database je zaveden s priimkom Stepiniks, datum prihoda v Dachau 7. december 1943, datum odpusta 21. julij 1944, kar verjetno sovpada $\mathrm{z}$ njegovo redno zaposlitvijo v Dachauu, podobno kot pri Krajncu. Že nekaj dni po prihodu $\mathrm{v}$ taborišče so ga kot kemika vključili $\mathrm{v}$ delo Rascherjeve skupine, nadaljeval pa ga je tudi kasneje, ko je skupino prevzel Plötner. Delal naj bi izključno pri pripravi tablet za strjevanje krvi, skupaj z Jankom Puflerjem ${ }^{\text {LI }}$. V dokumen-

XLVIII V metu kladiva je osvojil kolajne na 6 predvojnih Balkanskih igrah, od tega 3 zlate. Štirikrat je izboljšal državni rekord v tej disciplini. Tudi po vojni je še tekmoval in je bil zastavonoša slovenske atletske reprezentance na prvem povojnem jugoslovanskem atletskem prvenstvu (Zagreb, 1945), kjer je osvojil 6. mesto v metu diska, v metu kladiva pa je bil drugi. Leta 1946 je na balkanskih igrah v Tirani osvojil bronasto medaljo v metu kladiva ${ }^{43}$.

XLIX Fotografija je nastala 14. 9. 1941 na atletskem mitingu za pokal Iva Scapola na stadionu v mestu Schio pri Vicenzi, ki ga je dve leti prej otvoril Benito Mussolini. Na tem tekmovanju so nastopili vsi najboljši italijanski lahkoatleti, $\mathrm{v}$ dogovoru $\mathrm{z}$ njihovo atletsko zvezo pa prvič po priključitvi Ljubljanske pokrajine Italiji tudi trije naši tekmovalci. V metu kladiva je zmagal italijanski prvak Teseo Taddia, Stepišnik je bil drugi, tretji pa je bil Cecchini.

L V dopisu Stepišnikove žene Poldke je navedeno, da so v njihovo stanovanje vdrli oboroženi belogardisti in odpeljali moža ter dve sosedi. Kot sodelavca OF so ga nameravali še isto noč ustreliti na Urhu, vendar so ga zato, ker je sama doživela živčni zlom in so jo morali odpeljati v bolnišnico, na koncu odpeljali v zapor, ne na streljanje.

LI Janko Pufler (1905-1950?) je bil steklar v Hrastniku, kjer so ga že leta 1926 sprejeli v komunistično partijo, leta 1928 pa so ga izgnali, tako da je naslednja leta preživel v različnih državah Evrope. Spomladi 1937 je prišel iz Sovjetske zveze kot prostovoljec v Španijo, kjer je bil v vlogi inštruktorja. Po koncu državljanske vojne je bil v več francoskih taboriščih. Julija 1942 ga je aretiral Gestapo v Gradcu, februarja 1943 pa so ga zaprli v taborišče Dachau. Po nekaj tednih so ga dodelili za steklopihača v 'poskusni postaji', kasneje pa naj bi kot laborant sodeloval pri razvoju tablet za strjevanje krvi, a je verjetno, da je bil predvsem zadolžen za pripravo in čiščenje steklovine. Leta 1944 so ga preselili v podružnico Schlachters in tik pred koncem vojne v Lochau. V nekaterih virih je naveden kot Hans Puffler ali Janco Pufler. Decembra 1945 so ga postavili za direktorja steklarne Hrastnik, a so ga oktobra 1946 razrešili zaradi spora s političnimi organizacijami v podjetju. Proti koncu tega meseca je v nočni izmeni izbruhnil požar, zaradi katerega je prišlo do zastoja v proizvodnji. To so oblasti prikazale kot sabotažo in so zato na celjskem okrožnem so- 
taciji za obnovo procesa piše, da naj bi pomagal Puflerju pri pripravi pektinskih tablet ${ }^{\mathrm{LII}}$ in da naj ne bi sodeloval pri poskusih na internirancih.

V drugi polovici oktobra 1944 je bil na dopustu v Ljubljani in na Jesenicah, kjer je pridobil potrdilo, da so ga pripravljeni zaposliti v železarni na področju, pomembnem za nemško vojaško industrijo. Na osnovi tega so mu v Dachauu dovolili, da se s 1. novembrom 1944 vrne domov. Istega meseca se je zaposlil v šamotarni železarne na Jesenicah. Po vojni so ga postavili za ,delegata' Ministrstva za industrijo in rudarstvo $\mathrm{v}$ Industriji metalnih polizdelkov (kasnejši Impol) v Slovenski Bistrici, kar je ustrezalo funkciji direktorja. Kot član državne delegacije je v začetku leta 1947 nekaj mesecev pregledoval nemška kemična podjetja glede vojnih reparacij. V času pomanjkanja materialov je sam poskrbel za pripravo mase za šamotno oblogo talilne peči v Impolu, ki pa, verjetno zaradi nekakovostnih surovin, ni zdržala dolgo, kar so oblasti prikazale kot sabotažo. Aretirali so ga 30. septembra 1947 in na Diehl-Oswaldovem procesu obsodili na smrt. Zdi se verjetno, da so kazen izvršili šele leta $1950^{\mathrm{LIII}}$, obstajale pa naj bi tudi priče, ki so se oglasile svojcem in naj bi ga videle še kasneje, tako da naj bi po mnenju nekaterih umrl šele leta 1974 (izročilo družine Stepišnik).

Karel Barle (1910-1948) iz Šmartnega pri Slovenj Gradcu je bil inženir kemije. Študij je začel v Ljubljani, zaključil pa v Avstriji, kamor je leta 1934 emigriral po nalogu Komunistične partije Jugoslavije. Bil je prostovoljec Španske državljanske vojne, ko se je ta končala pa je bil v več francoskih in nemških taboriščih. Aretirali so ga v Brestu v Franciji konec novembra 1941, v Dachau pa je prispel 22. avgusta 1942 in od marca 1943 delal kot kemik najprej pri ohlajevalnih poskusih, kasneje pa je sodeloval pri ra-

dišču izvedli sojenje proti Puflerju, njegovemu delavcu Jožetu Bengaliji in še dvema sodelavcema. Po pritožbi je višje sodišče sodbo razveljavilo in vrnilo zadevo prvostopenjskemu sodišču pod spremenjenim senatom. $\mathrm{Na}$ Diehl-Oswaldovem procesu so Puflerju poleg sabotaže očitali še vrsto drugih dejanj iz časa vojne in pred njo. Tako so ga na primer obdolžili, da je bil sodelavec Gestapa že od leta 1928 (kar je priznal), pri čemer so Gestapo ustanovili šele leta 1933. Obsojen je bil na smrt. Jože Benegalija je bil na istem procesu obsojen na 18 let prisilnega dela, a so ga iz zapora izpustili leta 1954.

LII Dokaj nelogično se zdi, da bi Stepišnik, ki je bil kemik z izkušnjami, pomagal Puflerju, steklarju, pri pripravi pektinskih preparatov. Bolj verjetno je obratno. Navedeno je tudi, da naj bi stika s poskusnimi osebami sploh ne imel, kar je prav tako malo verjetno, glede na najdene njegove zapiske o rezultatih preiskav na poskusnih osebah.

LIII Po uradnem zapisniku naj bi vse na smrt obsojene na prvem dachauskem procesu usmrtili 12. maja 1948, a so v osebnem arhivu Borisa Kraigherja $^{44}$ našli rokovnik za vpenjanje listov manjšega formata, ki je vseboval predvsem kratke zabeležke. Pri 18. oktobru 1952 je najprej navedeno ime Nikič, kar bi lahko pomenilo Boris Nikič (s pravim imenom Niko Šilih, pomočnik načelnika Udbe za Slovenijo), sledijo priimki 24 zapornikov, obsojenih na smrt. Pri nekaterih je za imenom znak + , kar bi bilo mogoče razumeti kot oznako za likvidacijo, ne pa nujno. Nekatera imena nimajo te oznake, nekatera so zapisana v oklepaju, nekatera $\mathrm{z}$ znakom - pred imenom, nekatera pa so podčrtana. Kaj bi to pomenilo, ni znano. Poleg Stepišnika so bili navedeni in označeni s + še dachauski obsojenci Diehl, Oswald, Juranić, Ličen in Pufler. Krajnca na tem seznamu ni, prav tako ne Barleta. zvoju pektinskih tablet. Boris Krajnc je v preiskovalnem postopku natančno opisal Barletov prihod v Rascherjevo skupino. Pri tem je omenil tudi to, da mu je Barle povedal, da je v Španiji (v Albaceti) kot kemik izvajal mikrobiološke preiskave vode. Nadalje je povedal, da se je za vključitev Barleta v raziskave zelo zavzemal Rudolf Punzengruber (gl. op. XXXVII), ki je bil tudi s Koroške, ker je mislil, da bosta prijateljevala, a kasneje nista. Barle je bil v taborišču član prvega jugoslovanskega taboriščnega komiteja ${ }^{\text {IVV }}$. Kot kemik je sodeloval pri tehničnem delu priprave poročila o stanju $\mathrm{v}$ koncentracijskem taborišču Dachau ${ }^{\mathrm{LV}}$. Aprila 1945 je v Schlachtersu, kjer so vzpostavljali proizvodni obrat za pektinske tablete, spoznal bodočo ženo Reziko (Theresia, roj. Brüstle, 1925-1949) in se z njo poročil junija 1945. Osvoboditev je dočakal v dachauski podružnici Lochau na Predarlberškem v današnji Avstriji in se v domovino vrnil šele septembra 1945 . Zaposlil se je na Ministrstvu za industrijo in rudarstvo, kasneje pa v Centralnem komiteju KPS, kjer je bil sekretar ekonomske komisije. Aretiran je bil 8. avgusta 1947 in bil zaradi domnevnega sodelovanja s tujo obveščevalno službo in medvojnega

LIV Taboriščni komiteji so bile po nacionalnostih organizirane ilegalne protifašistične organizacije, ki jih je povezoval mednarodni taboriščni komite. Slovenski komunisti so organizirali jugoslovanski taboriščni komite (med jugoslovanskimi taboriščniki so namreč prevladovali Slovenci). Pomembna vloga taboriščnega komiteja je bila pomoč tistim rojakom, ki niso dobivali paketov pomoči od doma in tistim, ki so rabili zdravstveno pomoč, hkrati pa je odbor razširjal informacije o dogajanju v domovini in skrbel za moralo med zaporniki. Če je bilo mogoče, so svoje zanesljive člane razporejali na delovne naloge, kjer bi lahko pomagali drugim, ali poskušali preprečiti transporte svojih članov v uničevalna taborišča. Konec leta 1944 so se odločili ustanoviti širšo organizacijo taboriščnikov s protifašistično usmeritvijo, a je do ustanovitve prišlo šele aprila 1945. Z osvoboditvijo taborišča Dachau 29. aprila 1945 se je jugoslovanski narodnoosvobodilni odbor preoblikoval v Jugoslovanski nacionalni odbor ${ }^{36}$. Na dachauskih procesih je tožilstvo nastopalo s pozicije, da je bil taboriščni komite podaljšek Gestapa oz. da je šlo za 'provokatorsko' antifašistično organizacijo. To je bila ena od točk obtožnice pri Karlu Barletu, Borisu Krajncu in nekaterim drugim obtožencem na dachauskih procesih.

LV Šlo je za dve poročili, napisani v žepno beležnico z nevidnim črnilom, ki ga je izdelal Karel Barle. Prvo poročilo je napisal takratni sekretar taboriščnega jugoslovanskega partijskega komiteja Vlasto Kopač in v njem prosil KPS za usmeritve glede delovanja komunistov v taborišču. Drugo poročilo je pripravil sovjetski taboriščni partijski komite v ruščini, namenjeno pa je bilo sovjetskemu predstavniku v glavnem štabu NOV in POS. Beležnico s poročilom je ob vrnitvi v Slovenijo v jeseni $1944 \mathrm{~s}$ seboj prinesel Milan Stepišnik ${ }^{36}$. Iz izvlečkov izjav Borisa Krajnca in Milana Stepišnika med preiskavo v letih 1947/1948 je mogoče ugotoviti, da je Stepišnik ob odpustu iz Dachaua s seboj prinesel manjši zvezek ('notez'), ki naj bi ga z nevidno pisavo popisal 'Dil' (Branko Diehl), namenjen pa naj bi bil Krajncu. Stepišnik je povedal, da je v Dachauu skupaj z Barletom dodelal postopek, pri katerem je besedilo napisano $\mathrm{z}$ raztopino svinčevega nitrata, nevidno pisavo pa nato razvijejo $\mathrm{z}$ vodikovim sulfidom. Krajnčeva bodoča žena naj bi zvezek poslala Krajncu na Pokljuko, kjer se je pridružil partizanom, a tam ni bilo pogojev, da bi pisavo razvil. Pisavo naj bi kasneje razvila Neža Exel (inž. kemije, diplomirala 1939 kot Agneza Hillinger), ki je pisavo prepoznala kot Diehlovo, a je bila slabo čitliiva. Po mnenju Krajnčeve žene (zaslišanje 22. 11. 1947) naj bi v zvezku bili »važni podatki o delu in poskusih v lagerju «. Glede na to, da je bil Kopač soavtor članka, v katerem je opisana beležnica ${ }^{36}$, je bolj verjetno, da je poročilo pripravil on, kot pa da je bil avtor Diehl, kot je na osnovi pisave ocenila Neža Exel. 
"sodelovanja pri zločinskih poskusih" na prvem Dachauskem procesu obsojen na smrt $\mathrm{z}$ ustrelitvijo. Verjetno je umrl zaradi neznosnih razmer $\mathrm{v}$ zaporu še pred izvršitvijo smrtne obsodbe ${ }^{19,45}$. Njegovo ženo so na 6 . dachauskem procesu avgusta 1948 obsodili na smrt zaradi domnevnega vohunstva. V Arhivu Republike Slovenije je v Barletovem dosjeju iz obdobja preiskave za Diehl-Oswaldov proces shranjen njegov opis priprave različnih pektinskih preparatov, predvsem njihov razvoj v Dachauu, zelo malo pa o proizvodnji v Schlachtersu. Ti podatki so, glede na to, da je bil Barle kemik, gotovo bolj verodostojni od tistih, ki jih je v svojih spominih podal Franz Jauk (1904-1995) $)^{\mathrm{LVI}}$, po poklicu barvarski pomočnik, $v$ Dachauu pa taboriščni pisar bloka 5 in kasneje sodelavec v skupini Sigmunda Rascherja ${ }^{46}$.

Branko Diehl (1905-1950?) iz Celja je po maturi na celjski Realki leta 1923 začel s študijem kemije na Dunaju in ga naslednje leto nadaljeval v Ljubljani na Tehniški fakulteti, kasneje pa je diplomiral iz fizike in kemije na Filozofski fakulteti UL (1931). Leta 1933 so ga zaradi delovanja $\mathrm{v}$ Komunistični partiji Jugoslavije obsodili na 3 leta zapora. Po povratku se je za kratko zaposlil v rudniku v Mežici, a so ga kmalu ponovno aretirali, po 4-mesečni preiskavi pa se je vrnil v rudnik. Konec junija 1941 so ga v Žerjavu aretirali in kot znanega komunista zaprli, nato pa poslali $\mathrm{v}$ taborišče Dachau, kamor je prišel 15. septembra istega leta kot eden prvih Slovencev oz. Jugoslovanov. Nekaj časa je delal v laboratoriju taboriščne bolnišnice, sodeloval pa je tudi pri delu takoimenovane, malarične postaje, kjer so izvajali poskuse na taboriščnikih. Vendar naj bi Diehl opravljal samo mikroskopske analize krvi in komarjev ${ }^{\mathrm{LVII}}$.

V Dachauu je bil ob osvoboditvi tajnik Jugoslovanskega narodnega odbora, skupine predstavnikov različnih narodov, v kateri so bili predvsem člani Komunistične partije, za glavno nalogo pa je imela organizacijo povratka jugoslovanskih internirancev ${ }^{\mathrm{LVIII}}$. Po vojni je bil ,delegat Ministrstva industrije in rudarstva' (direktor) $\mathrm{v}$ rudniku v Mežici, glavni inšpektor za gozdarstvo pri Kontrolni komisiji Predsedstva vlade LR Slovenije in član ekonomske komisije Centralnega komiteja Komunistične partije Slovenije. Skupaj z Oskarjem Juranićem (ki je bil prav tako član Jugoslovanskega narodnega odbora) je pripravil povojno oceno delovanja KPJ $\mathrm{v}$ koncentracijskem taborišču Dachau. Aretirali so ga 16. septembra 1947 in na Dachauskem procesu obsodili na smrt zaradi domnevnega sodelovanja z Gestapom, dela na ,malarični

LVI Več o življenjski poti Franza Jauka je v sestavku ${ }^{47} \mathrm{H}$. Halbreinerja.

LVII Vlasto Kopač je v intervjuju s Petrom Vodopivcem ${ }^{50}$ leta 1986 povedal, da naj Barle sploh 'ne bi sodeloval pri poskusih' in da je samo 'seciral komarje in uši'.

LVIII Ob tem je odbor tudi evidentiral tiste internirance, ki so pred aretacijo sodelovali z belo gardo ali okupatorji. Zasliševali so jih že v Dachauu, nato pa organizirali njihov ločen transport v domovino, kjer so številne ustrelili brez sojenja, proti drugim pa so organizirali sodne procese $\mathrm{z}$ izredno nizkimi pravnimi standardi (prim. sestavek ${ }^{51}$ Tineta Velikonje iz leta 1995). postaji, povojnega ustanavljanja vohunske mreže in povojne sabotaže.

Mirko Pibernik (1905-1947) se je po maturi na ljubljanski realki leta 1924 vpisal na Tehniško fakulteto in iz kemije je diplomiral 1928 pod imenom Bogomir. Tema njegove diplomske naloge je bila oksidacija škroba za pripravo topnih oblik, o čemer je naslednje leto izšel članek Maksa Samca v reviji Kolloidchemische Beihefte ${ }^{48}$. Bil je tudi aktiven član Sokola in soavtor telovadnega priročnika ${ }^{49}$ (izšel 1933). Po odsluženem vojaškem roku v šoli za rezervne oficirje se je poročil in zaposlil v podjetju Medič-Zankl, tovarni olja, lakov in barv, ki je imelo en proizvodni obrat v Medvodah (kasnejši Color) in enega v Domžalah (kasnejši Helios). Pibernik je delal v obeh sočasno, tako da se je redno vozil med obema tovarnama. Marca 1941 so ga mobilizirali v enoto v Srbiji, a se je po kapitulaciji Jugoslavije uspel vrniti $\mathrm{v}$ Medvode, kjer je še naprej delal $\mathrm{v}$ istem podjetju. Med vojno je stanoval v Medvodah, kjer so v upravni stavbi podjetja poleg kemijskega laboratorija bila tudi stanovanja za zaposlene. Sodeloval je z Osvobodilno fronto in med drugim ilegalno tiskarno preskrboval s tiskarsko barvo, ki so jo delali v tovarniškem laboratoriju. V začetku leta 1944 je bil za kratko zaprt $v$ Ljubljani, morda $v$ povezavi $z$ delovanjem Miklavčeve skupine $\mathrm{e}^{\mathrm{LIX}} \mathrm{v}$ Medvodah.

Pibernikova družina je med vojno živela v Šiški (sprva pod italijansko zasedbo), tako da jo je le občasno obiskoval s kolesom. Ob povratku je večkrat s seboj vozil pakete za dachauske zapornike in jih oddal na pošti v Medvodah, ki so bile pod nemško zasedbo. Tudi po vojni je ostal zaposlen v tovarni barv in lakov v Medvodah, kjer je bil direktor do prihoda Vladimira Lična na ta položaj, Pibernik pa je postal referent direkcije kemične industrije pri slovenski vladi. Leta 1946 je bil član komisije za povojne reparacije pri jugoslovanski vojni misiji v Berlinu. Aretirali so ga 3. 11. 1947, v času preiskave pa je - po uradni verziji - naredil samomor, a je verjetneje, da je 19. novembra umrl zaradi posledic mučenja. Objavljeni so odlomki z zaslišanj, iz katerih je razvidno, da je (verjetno pod prisilo) menjal izpovedi, tako da so bile v skladu s sugestijami zasliševalcev. V Dachauu ni bil nikoli in njegovo ime se ne pojavlja v gradivih, ki jih hrani največji arhiv za obdobje nacizma $\mathrm{v}$ Nemčiji ${ }^{\mathrm{LX}}$, zato je absurdno, da je bil osumljen sodelovanja

LIX Ivan Miklavc (1890-1944) je bil podjetnik iz Medvod, ki si je med vojno prizadeval za ustanovitev pokrajinskega odbora Osvobodilne fronte za Gorenjsko in s skupino somišljenikov pripravljal organizacijske korake za vzpostavitev oblastnih struktur še pred pregonom Nemcev. Predvideli so tudi že nekatere kadrovske zasedbe, pri čemer so vključevali pripadnike krščanskih socialistov, članov Sokola in komunistov (ki so bili v manjšini), zato nekateri menijo, da Miklavc ni bil po volji takratnega vodstva $\mathrm{OF}^{52}$.

LX Na poizvedovanje v Arolsenskih arhivih sem dobil podatek, da Pibernika ni v nobenih dokumentih, povezanih z Dachauom, niti kje drugje $\mathrm{v}$ arhivskem gradivu in da ni jasno, zakaj se njegovo ime pojavlja na jetniški evidenčni kartici Vladimirja Lična. V zborniku Dachauski proce$\mathrm{si}^{54}$ je navedeno, da naj bi bil med vojno v Dachauu, a kaže, da navedba ni pravilna (Anton Pibernik, osebna komunikacija). Možna razlaga, zakaj je bil Pibernik naveden na Ličnovi jetniški kartici, je, da mu je redno pošiljal pakete, vendar taki pripisi na karticah niso bili običajni. 
z Gestapom. Očitali so mu tudi sodelovanje s tujo obveščevalno službo in sabotažne dejavnosti $v$ povezavi $\mathrm{z}$ vžigom ricinusovega olja, kot je razloženo v nadaljevanju.

Vladimir Ličen (1912-1950?) je bil rojen v Trstu, a se je družina po italijanski zasedbi po prvi svetovni vojni preselila v Slovenijo. Maturiral je na ljubljanski realki leta 1930, diplomiral pa je na Filozofski fakulteti v Ljubljani iz kemije leta 1936. Vojaški rok je služil v Kruševcu v Srbiji. Leta 1938 se je zaposlil v tovarni barv in lakov Medič-Zankl v Medvodah. Tik pred začetkom vojne v Jugoslaviji je bil mobiliziran, a so ga v Sarajevu ujeli in odpeljali v taborišče v Osnabrücku, nato pa so ga predali italijanskim oblastem, kjer je bil zaprt v več taboriščih za vojne ujetnike, od koder je ušel septembra 1943 in se vrnil v Trst ${ }^{53}$. Tam so ga zaradi ponarejenih dokumentov aretirali in poslali $\mathrm{v}$ taborišče Dachau (prispel je 24. novembra).

$\mathrm{V}$ taborišču je delal v bolnišničnem laboratoriju do 25. aprila 1944, ko so ga izpustili, za kar naj bi posredoval tudi Leon Rupnik (takratni ljubljanski župan in komandant domobranskih enot). Na zaporniški kartici je (ni jasno, zakaj) pripisano ime inž. Mirka Pibernika. Po izpustitvi je delal v Celovcu v tovarni kvasa in špirita, po osvoboditvi pa se je vrnil v Medvode, kjer je bil najprej obratovodja in kasneje direktor tovarne. Uvedel je nekatere spremembe v postopkih proizvodnje, za kar je bil tudi večkrat nagrajen. Ker je je bilo težko dobiti dovolj lanenega olja iz uvoza, je v proizvodnjo vpeljal domače ricinusovo olje, o čemer naj bi se predhodno posvetoval s strokovnjaki z univerze in inštitutov, opravili pa naj bi tudi več preliminarnih analiz. Ko je 3. oktobra 1947 v tovarni prišlo do samovžiga ricinusovega olja, so oblasti to označile kot sabotažo v navezi s tujimi vohunskimi agenturami. Na Dachauskem procesu je bil med drugim obtožen, ker »je dobil nalogo organizirati bakteriološki laboratorij« v taboriščni bolnišnici. Po odpustu ga je tam nasledil Mirko Košir. V preiskovalnem zaporu je bil od 3. oktobra 1947, aprila 1948 pa je bil obsojen na smrt.

Mirko (Miroslav Jožef) Košir (1905-1951) je na Filozofski fakulteti UL diplomiral iz kemije, fizike in fizikalne kemije leta 1929. Kemijo je učil najprej dve leti v Kikindi, potem pa v Kranju. Po sojenju mladim komunistom leta 1934, kjer je bil oproščen, se je zaposlil v škrobarni v Domžalah, kasneje pa v Rudarski družbi Trojane, kjer so kopali antimonit. Pred 2. svetovno vojno je bil aktiven v delavskem gibanju in je postal član vodstva Komunistične partije Slovenije. Ob izbruhu 2. svetovne vojne so ga zajeli Nemci, odpeljali v svoja taborišča, nato pa predali Italijanom, ki so ga zaprli v svoja. Po kapitulaciji Italije se je pridružil partizanom, kjer so ga vključili v kulturniško skupino, med nemško ofenzivo pa se je vrnil v Ljubljano. Po aretaciji so ga poslali v Dachau, kamor je bil sprejet 12. 2. 1944. Ko so aprila 1944 iz taborišča Dachau izpustili Vladimira Lična, je prišel na njegovo mesto v taboriščni bolnišnici, kjer je opravljal analize krvi, urina in sputuma. Nato so ga 11. 10. 1944 prepeljali v Sachsenhausen, kjer je kot kemik delal v tovarni granat.
Ob koncu vojne se je preko Prage, Budimpešte in Beograda vrnil v Ljubljano. Deloval je kot prevajalec in predavatelj na ljubljanski univerzi, kjer je bil od 1946 izredni profesor na Tehniški fakulteti in honorarni predavatelj za družbene vede na Gospodarski fakulteti in Akademiji upodabljajočih umetnosti ${ }^{17}$. Aretirali so ga 9. aprila 1948 in še isti mesec obsodili na 20 let zapora. Iz slovenskih zaporov so ga kasneje premestili na Goli otok, kjer so ga ob prihodu pretepli in je 11. 3.1951 zaradi posledic poškodb umrl.

Vladimir Premru (1902-1949) je bil prvotno osumljenec $\mathrm{v}$ dachauskih procesih, a so ga zaradi pomanjkanja dokazov izpustili, kasneje pa obsodili zaradi domnevnega sodelovanja $\mathrm{z}$ Informbirojem in zaprli na Goli otok, kjer je umrl oktobra 1949. Na Medicinsko fakulteto UL se je vpisal v študijskem letu 1920/21, s študijem pa je nadaljeval v Zagrebu in Gradcu. Leta 1924 se je prepisal na Filozofsko fakulteto v Ljubljani, kjer je diplomiral iz kemije in fizike leta 1929. Najprej je poučeval na Državni tehniški srednji šoli, kjer je leta 1930 izšel njegov učbenik Elektrokemija. Od ustanovitve Banovinskega inštituta za raziskovanje in zdravljenje novotvorb (1938) je kot neplačan sodelavec vodil tudi kemijski laboratorij (inštitut je imel »klinični, kemični in kemobiološki« laboratorij ${ }^{55}$, ki jih je verjetno vse, glede na skromno kadrovsko sestavo inštituta, vodil Premru). Znan je tudi kot prevajalec leposlovja in ekspresionistični pesnik. Leta 1941 je v soavtorstvu z dr. Leom Šavnikom objavil kratko preliminarno raziskovalno poročilo o karcinogenem delovanju različnih preparatov na osnovi stilbena (1,2-difeniletena) ${ }^{56} \mathrm{v}$ reviji Zeitschrift für Krebsforschung, naslednje leto pa v isti reviji celovitejše poročilo ${ }^{57}$ o isti temi. Novembra 1943 so ga aretirali in poslali v taborišče Dachau, kamor je bil sprejet 8 . januarja 1944. V sprejemnem listu v taborišče je zaveden kot učitelj kemije iz Ljubljane. Rojen je bil v Boštanju, njegovi starši pa so kasneje živeli v Celju, tako kot Krajnčevi. Iz Dachaua, kjer je od marca 1944 delal v skupini dr. Rascherja, je bil kasneje premeščen v podružnico Lochau.

Ko se je po osvoboditvi peš vračal domov, so ga zajeli Francozi in zaprli v njihovo prehodno taborišče Tisis, tako da se je vrnil šele avgusta 1945. Po povratku je najprej delal kot pomočnik ravnatelja srednje tehniške šole, maja 1946 pa je postal načelnik oddelka za strokovno šolstvo na Ministrstvu za industrijo in rudarstvo LRS ${ }^{58}$. Njegov sin Lev Premru (1931-2005) je bil prav tako interniran na Goli otok, a je preživel jetništvo in doktoriral iz kemije 1965. V naziv docenta je bil izvoljen 1971 in v naziv izrednega profesorja 1974, kariero pa je nadaljeval v industriji. Znan je predvsem kot direktor Leka v času njegove intenzivne širitve (1980-88) ${ }^{59}$.

Mitja Sark (1919-2000) je maturiral na ljubljanski realki leta 1939 in se istega leta vpisal na študij kemije na Tehniški fakulteti. Že kot študent je bil vključen v delo Osvobodilne fronte v Ljubljani, kjer so ga belogardisti januarja 1943 aretirali, italijanska uprava pa ga je marca poslala v taborišče Visco pri Palmanovi. Konec julija se je vrnil v Ljubljano, kjer 
so ga 5. novembra ponovno aretirali in poslali v taborišče Dachau, kamor je prispel 28. 11. 1943. Od aprila 1944 naprej je delal kot kemik na ,malarični postaji in ostal v taborišču do začetka junija 1945, ko se je s prvim organiziranim transportom vrnil v Slovenijo. Takoj se je zaposlil v laboratoriju za nadzor živil pri Ministrstvu za ljudsko zdravstvo v Ljubljani, ob delu pa je nadaljeval s študijem.

Tik pred koncem študija je bil 19. septembra 1947 aretiran in 22. maja 1948 obsojen na 18,5 let zapora. Obsojen je bil za sodelovanje pri poskusih na taboriščnikih pod vodstvom dr. Klausa Schillinga, ter ker naj bi po vojni dajal lažne informacije o svojem delovanju v Dachauu ${ }^{\mathrm{LXI}}$. Kazen so mu kasneje dvakrat znižali, $\mathrm{z}$ amnestijo novembra 1954 pa je bil izpuščen. Kmalu se je zaposlil kot kemik na Inštitutu za elektrozveze. Diplomiral je šele leta 1956 z novo nalogo »Pridobivanje lahkih luknjičavih apnenih betonov iz apna in kremena oziroma silikatov v avtoklavu«, ki jo je pripravil pod mentorstvom prof. Janka Kavčiča. Decembra 1961 se je zaradi politično motiviranih konfliktov ${ }^{\mathrm{LXII}}$ odločil, da zapusti Slovenijo in je za kratek čas delal v Nemčiji kot nekvalificiran delavec ${ }^{\mathrm{LXIII}}$, kasneje pa se je preselil na Švedsko, kjer je živel v okolici Stockholma.

Od februarja 1962 naprej je delal kot kemik v industrijskem laboratoriju, nato je bil asistent na švedskem državnem inštitutu za javno zdravje, kjer je bil predvsem zadolžen za kontrolo izdelkov (predvsem živil), ki so priha-

LXI Vprašanje je, zakaj Sarku niso sodili že na Diehl-Oswaldovem procesu, saj so ga aretirali kmalu po Barletu in Diehlu, mesec in pol pred Krajncem. Obtožnica je bila dokaj podobna (sodelovanje z Gestapom, izvajanje poskusov na taboriščnikih, neresnično navajanje podatkov o medvojnem delovanju), le da mu niso očitali povojnega delovanja za tuje obveščevalne službe in/ali sabotaž. Možna razlaga za Sarkovo ločeno sojenje bi bila, da je v vodstvu državne varnosti delal Dušan Bravničar (191-2004), rojen istega leta kot Sark, prav tako študent kemije (vpisan v 1. letnik 1937) in član vodstva KP v Ljubljani že leta 1941. Vsi ostali kemiki na dachauskih procesih so bili starejši. Bravničar je sodeloval pri preiskavi proti Martinu Presterlu, ključni priči tožilstva na Diehl-Oswaldovem procesu ${ }^{60}$. Morda je Bravničar vedel, kako stroge bodo sodbe na prvem procesu in je Sarku kot kolegu in revolucionarno usmerjenem študentu namenil ločeno sojenje. Bravničar je zaključil študij kemije na 1. stopnji leta 1966, pred tem pa je opravljal nekatere vidne politične in administrativne funkcije v Sloveniji. Nazadnje je bil direktor Inštituta za zgodovino delavskega gibanja; upokojil se je leta $1962^{61}$.

LXII Sark je imel abonirano kosilo v gostilni Bellevue v Šiški. Nekega dne mu je direktorica sporočila, da mu ne smejo več postreči. Gostinsko podjetje je namreč dobilo od partijskega komiteja iz Šentvida (v tistem času je Sark delal v tovarni Keramika v Šentvidu oz. Vižmarjih pri Ljubljani - to je bila ena od proizvodnih enot Inštituta za elektrozveze) ukaz, da kot bivši gestapovec in zapornik ne sme več dobivati hrane. Sarka je to razjezilo in je tožil partijski komite in dva posameznika za razžalitev časti, ob tem pa se je skliceval na člen iz kazenskega zakonika, da tistega, ki bivšemu zaporniku očita prestano zaporno kazen, lahko kaznujejo z enim letom zapora. Tožbo so mu večkrat odsvetovali in mu grozili s posledicami, odvetnik Ljuba Prenner, ki je bil sam večkrat preganjan zaradi opozarjanja na nepravilnosti v slovenskem sodstvu, pa ga je podprl. Sodišče je razsodilo, da obtoženci niso krivi in pri tem utemeljevalo dopustnost očitka prav s Sarkovo obsodbo na dachauskem procesu. Vse pritožbe na sodbo (celo na jugoslovansko ustavno sodišče in maršalu Titu) so bile odbite.

LXIII F.Derganc navaja ${ }^{65}$, da je Sark živel v Belgiji, vendar je bil tam morda le kratek čas pred selitvijo na Švedsko ali pa sploh ne. jali iz uvoza, zadnjih 5 let do upokojitve (1988) pa kot razvojni inženir na tehniški visoki šoli v Stochkolmu. Sodba z dachauskega procesa je bila razveljavljena leta 1971. Po osamosvojitvi Slovenije je Sark dobil slovenski potni list in je večkrat prišel na obisk v domovino, kjer je med drugim na Televiziji Slovenija sodeloval na omizju o povojnih montiranih procesih ${ }^{62}$. Tridesetstranski pogovor z Mitjem Sarkom je izšel leta 1996 v Novi reviji ${ }^{63}$.

Boris Fakin (bolj znan pod psevdonimom Igor Torkar; 1913-2004) je diplomiral iz kemije 1942 in sicer z nalogo »Grignardove sinteze propionske, izomaslene, valerianske in izovalerianske kisline« (mentor prof. Ladislav Klinc). Zaradi sodelovanja z Osvobodilno fronto je bil v Ljubljani konec leta 1943 aretiran in od 20. 1. 1944 zaprt v Dachauu, od koder je bil 11. 10. 1944 premeščen v Sachsenhausen (kasneje v podružnico Klinkerwerk Oranienburg) ${ }^{64}$, kjer je ostal do konca vojne. V Dachauu je delal v kliničnem laboratoriju taboriščne bolnišnice. Med drugim naj bi opravljal analize urina in blata, pri čemer obstaja pričanje več zapornikov, da je, če je bilo treba, potvoril rezultate preiskav, da bi zadržal slovenske internirance dalj časa v bolnišnici in jih s tem rešil transporta ali težkega dela.

Po vojni je bil zaposlen na republiškem ministrstvu za industrijo in rudarstvo, nazadnje kot direktor direkcije za kemično industrijo. Aprila 1948 je bil aretiran in obsojen zaradi domnevnega sodelovanja z Gestapom, katerega agent naj bi bil. Obsojen je bil na 8 let in 9 mesecev zapora s prisilnim delom, po pritožbi pa so kazen podaljšali na 12 let in naknadno znižali na 6 let strogega zapora, od katerih je prestal 4 leta, nato pa so ga pogojno izpustili. Sodba je bila razveljavljena leta 1971. Od leta 1954 je bil učitelj na Akademiji uporabljajočih umetnosti UL, kjer je predaval predmet Tehnologija slikarskih, kiparskih in grafičnih materialov. O svojih izkušnjah s povojnimi procesi je napisal roman Umiranje na obroke (1984), ki je verjetno njegovo najbolj znano delo.

\section{Razveljavitev obsodbe}

Do razveljavitve sodb iz dachauskih procesov je prišlo postopoma, saj je sprva moralo dozoreti spoznanje o krivičnosti sojenja, kasneje pa so morali rešiti vprašanje, kako s čim manj politične škode za vladajočo elito predstaviti ničnost sodb. Da so se o tem sploh sprožala vprašanja, gre $\mathrm{v}$ prvih letih po procesu v veliki meri zasluga vdovam obsojenih na smrt ${ }^{\mathrm{LXIV}}$, kasneje pa tudi tistim, ki so bili obsojeni na zaporne kazni, a so bili po nekaj letih pomiloščeni in/ali začasno izpuščeni. Pomembne so bile tudi aktivnosti združenj taboriščnikov, ki so pozivala $\mathrm{k}$ rehabilitaciji

LXIV Ivanka Krajnc je na primer skupaj z drugimi vdovami umorjenih na dachauskih procesih pisala pismo ženi jugoslovanskega predsednika, Jovanki Broz, glede (verjetno obnove) procesa proti njihovim možem. To pismo in vlogo za rehabilitacijo B. Krajnca je v šestdesetih prinesla tudi na vodstvo študentske organizacije UL, ker je v času razcveta študentskih gibanj po letu 1968 računala na njihovo pomoč ${ }^{66}$. 
nekdanjih sojetnikov, in združenja nekdanjih španskih borcev, saj so številni obsojenci bili nekdanji prostovoljci španske državljanske vojne.

V analizi obsodbe Borisa Krajnca, ki je bila osnova za razveljavitev sodbe (podobno pa bi lahko navedel še za druge v tem članku omenjene kemike, pa tudi druge obsojene) je jasno navedeno, da o agentski navezavi na Gestapo ne more biti govora. Glede pridobivanja agentov Gestapa obstaja vrsta zgodovinskih virov. Resnični agenti Gestapa bi namreč morali biti evidentirani na drugačen način, o njih bi morala obstajati evidenca nalog, poročanj in izplačil, tega pa za obsojene na dachauskih procesih ni bilo. Poleg tega so agente pridobivali predvsem za protiobveščevalno delo na terenu in agentov ne bi pošiljali v taborišča, taborišča pa so imela tako ali tako vzpostavljen svoj sistem pridobivanja podatkov in urejanja odnosov med zaporniki. Bolj verjetno je, da je Krajnc v Begunjah pod grožnjo streljanja podpisal splošno izjavo o lojalnosti, čeprav je med zaslišanjem navedel, da se je s podpisom obvezal, da bo delal za veliko Nemčijo po direktivah Gestapa. Izjavo o lojalnosti, ki naj bi jo podpisal v Begunjah, je omenil npr. Stane Oswald v zaslišanjih, vendar ta ne šteje kot soglasje $\mathrm{k}$ sodelovanju z Gestapom v vlogi agenta.

Obtožnica je Krajncu in drugim, ki so delali v poskusni postaji taborišča Dachau, očitala kaznivo dejanje vojnega zločinstva. V razveljavitvi sodbe je utemeljeno zapisano, da pri poskusih niso sodelovali naklepoma. Naveden je tudi sklic na povojne procese v Nemčiji, kjer so sodelavce pri poskusih na ljudeh sodišča vabila zgolj kot priče, ne pa kot storilce dejanj. Nelogično bi tudi bilo, da bi sodili tehničnim sodelavcem, medtem ko številnim njihovim nadrejenim niso sodili. Pri tem je prevladalo spoznanje, da nekdanji taboriščniki tudi po izpustitvi niso imeli možnosti izbire in so bili prisiljeni še naprej delati v skupinah, ki so jih rekrutirale, čeprav ne več v statusu zapornika. Sicer so s tem pridobili nekatere privilegije, ki jih taboriščniki niso imeli (boljšo hrano, občasne izhode iz taborišča, manjše tveganje za premestitev in delo do popolne izčrpanosti), kar pa ne pomeni, da so delo opravljali po lastni želji.

Poleg tega so v sedemdesetih letih zaslišali še številne dodatne priče, ki so kar po vrsti omenjale, da so jim Krajnc in ostali v taborišču pomagali. Krajnc je na primer dobival pakete $\mathrm{z}$ zdravili, ki so jih dobili oboleli taboriščniki mimo zaporniške bolnišnice. $\mathrm{V}$ prid Krajncu so pričali Tibor Škerlak, ki je Krajnca opisal kot zelo delavnega, poštenega in skromnega, Dušan Stucin, ki je pohvalil Krajnčev trden značaj in revolucionarno usmerjenost, in Bojan Držaj, Krajnčev diplomant, ki ga je pohvalil kot predavatelja in ga prikazal kot ,revolucionarja iz prepričanja.

Kot posreden dokaz, kako je Krajnčev položaj bil privilegiran, so na montiranem procesu navedli, da je lahko prišel domov na dopust in se potem prostovoljno vrnil na delo $\mathrm{v}$ skupino dr. Rascherja. Pred razveljavitvijo sodbe je sodišče pridobilo pisma, ki jih je Krajnc pisal svoji mami. Iz tistega, ki je datiran s 17. decembrom 1943, je razvidno, da je edini dopust, ki ga je dobil maja 1944, verjetno zakasnjen dopust za tistega, ki mu ga je Rascher obljubil za božič 1943, ko mu je uspelo Krajnca dobiti nazaj v svojo skupino. Ker so bili čez praznike dopusti prepovedani, je Rascher obljubil, da ga bo poslal na dopust, čim bo zapora $\mathrm{v}$ januarju ukinjená.

V pismu, ki ga je materi poslal 31. 12. 1943, pa je Krajnc opisal dogajanje $\mathrm{v}$ zvezi $\mathrm{z}$ njegovim odpustom iz taborišča in zaposlitvijo v skupini dr. Rascherja. Opisal je, kako je verjel, da se bo z odpustom lahko vrnil domov, da pa so mu zadnji hip sporočili, da mora $\mathrm{z}$ vlakom v Berlin, kjer se mora najprej javiti policiji, potem pa skupini za razporejanje dela. Ravno ko je zvedel, da mora v Berlin, je baje prišel mimo dr. Rascher in se zelo razburil, ker je menil, da bodo Krajnca v Berlinu uporabili za odkopavanje ruševin. $\mathrm{Z}$ avtom ga je odpeljal nazaj na poskusno postajo ter začel urejati zadeve. Šele 22. 12. je Rascher dobil dovoljenje za zaposlitev Krajnca v svoji skupini, do takrat pa je bil Krajnc še naprej jetnik $v$ taborišču.

Sodišče ob razveljavitvi sojenja ni videlo dokazov za vojno zločinstvo, poleg tega naj bi večino časa delal na pektinskih preparatih. O delovanju ,poskusnih postaj' naj bi že takoj, ko se je pridružil partizanom, pripravil poročilo za vojaško sodišče IX. korpusa, o razmerah v taborišču pa naj bi poročal že iz Dachaua, a teh poročil sodišče leta 1948 ni pridobilo in ne preverjalo.

Glede, špijonskih podatkov in poročila o delu na univerzi', ki naj bi jih posredoval tuji obveščevalni službi, na sojenju ni bilo podanih nobenih dokazov, prav tako ne za škodljivo delovanje po direktivah tuje obveščevalne službé. To bi lahko bila britanska služba $\mathrm{v}$ navezavi s Krajnčevo udeležbo na sestanku trgovske delegacije za področje kemijske industrije v Veliki Britaniji. Na ta sestanek naj Krajnc sploh ne bi želel iti, ker ni znal angleško, a je vseeno moral, skupaj s še tremi kemiki iz drugih republik (od katerih je samo eden znal angleško).

$\mathrm{Na}$ osnovi kritične obravnave obtožb in novih dejstev je Javno tožilstvo SRS 7. aprila 1976 Vrhovnemu sodišču SRS predlagalo obnovo kazenskega postopka proti obtoženim v Diehl-Oswaldovem procesu. Vrhovno sodišče je predlog tožilstva sprejelo 22. junija 1976, pri tem pa zadevo predalo v obravnavo Okrožnemu sodišču v Ljubljani. To je 26. julija, po umiku prvotne obtožnice s strani javnega tožilstva, razveljavilo sodbo in ustavilo kazenski postopek. Politika se je uspela poenotiti in opredeliti do dachauskih procesov šele leta 1984, ko je bilo 11. julija objavljeno skupno sporočilo predsedstva Centralnega komiteja Zveze komunistov Slovenije (CK ZKS) in predsedstva Republiške konference Socialistične zveze delovnega ljudstva (RK SZDL). Aprila 1986 se je 10. kongres ZKS zavzel za popolno odpravo posledic obsodb v dachauskih procesih, kar so nekateri interpretirali kot politično rehabilitacijo obsojencev ${ }^{\mathrm{LXV}}$.

LXV Nekateri kritiki postopka razveljavitve procesa menijo, da umik obtožnice ne pomeni ustrezne razjasnitve dejstev in oprostitve za očitana dejanja, prav tako pa ni ustrezno enačenje 'zavzemanja za popolno odpravo posledic' s pravo politično rehabilitacijo. Po mnenju nekaterih bi bila pravična razrešitev šele obsodba tistih, ki so krivi, da je do procesa in obsodbe sploh prišlo ${ }^{68}$. 
Obsodbe so prizadele številne družine: Sarkova družina je razpadla, Barletova sta imela dve leti starega sina, ki so ga vzgajali sorodniki in rejniki. Ko so Stepišnikove pregnali iz stanovanja $\mathrm{v}$ Slovenski Bistrici, so prišli živet $\mathrm{v}$ Ljubljano h Krajnčevi ženi Ivanki, kasneje pa so izselili tudi njo. Razveljavitev sodbe je prišla, ko so bile žene obsojenih stare že 55 let in več. Vrnili so jim nekaj odvzetega premoženja, niso pa jim mogli vrniti svojcev. Še več: za točne datume in kraje usmrtitve in pokopa svojci večine obsojencev še vedno ne vedo, čeprav je po slovenski osamosvojitvi Arhiv Republike Slovenije poskušal najti ustrezne podatke. Krajnčeva žena naj bi bila zaradi nenehnih prizadevanj za dosego rehabilitacije pod stalnim policijskim nadzorom vse do leta $1983^{19}$. O življenju po obsodbi moža je iskreno spregovorila ${ }^{67} \mathrm{z}$ novinarko Ranko Ivelja ${ }^{\mathrm{LXVI}}$ leta 2003. V sestavku so omenjeni tudi dotlej javnosti neznani arhivski podatki o tem, da naj bi bili nekateri domnevno ustreljeni obsojenci živi še leta 1952. Za Krajnca je bolj verjeten podatek iz pričevanja Antona Debevca, ki je pripravil prvo analizo dachauskih procesov (sicer interni dokument Udbe). Povedal je, da se je ob pripravi poročila (1951) dve leti srečeval z na smrt obsojenimi, da pa je Barle umrl zaradi bolezni in izčrpanosti že nekaj dni po obsodbi, Krajnc pa po kakšnem letu ${ }^{19}$.

Univerza v Ljubljani je maja 1997 ustanovila komisijo za rehabilitacijo univerzitetnih učiteljev. Ta komisija je zbrala gradiva in za senat pripravila izhodišča za razpravo in predlog sklepa. Točko so obravnavali na seji senata 15 . 1. 1998 in na njej rehabilitirali vse iz političnih razlogov odstranjene učitelje UL, med njimi tudi Borisa Krajnca in Mirka Koširja. Ker seznam takrat še ni bil popoln, je komisija $\mathrm{z}$ delom nadaljevala ${ }^{69}$.

\section{Zaključek}

$\mathrm{V}$ psevdomedicinske poskuse $\mathrm{v}$ nemških koncentracijskih taboriščih so vključili več kot 27000 jetnikov, od katerih jih je zaradi poskusov umrlo skoraj $4400^{70}$. Številni teh poskusov so potekali v taborišču Dachau, kjer sta bili najbolj znani skupini dr. Rascherja in dr. Schillinga, v obojih pa so kot tehnično in pomožno osebje sodelovali tudi nekateri Slovenci, med njimi več kemikov. Po vojni so jim sodili na takoimenovanih dachauskih procesih v Ljubljani, kjer so jih, tudi zaradi sodelovanja pri teh poskusih, obsodili za vojno hudodelstvo. Hkrati so od njih izsilili še priznanja za druga

LXVI V tem članku je Branko Diehl napačno naveden kot filozof, kar se pojavlja tudi v nekaterih drugih virih. Vendar pa je Diehl diplomiral iz kemije in fizike na Filozofski fakulteti. Naravoslovci, ki so študirali na tej fakulteti, so bili večinoma kasnejši profesorji v srednjih šolah, za razlikovanje od inženirjev kemije, ki so študirali na Tehniški fakulteti, pa so jih nekateri imenovali kar 'filozofi'. V istem članku je Milan Stepišnik označen kot doktor kemije, vendar to ne drži. Tekmovanje v Italiji, na katerem Stepišnik ni želel pozdraviti s fašističnim pozdravom, je njegov sin datiral s 'tik pred začetkom vojne', vendar gre za tekmovanje septembra 1941. dejanja, predvsem za sodelovanje z Gestapom v vlogi agentov, povezovanje s tujimi obveščevalnimi službami, spodkopavanje delovanja naprednih taboriščnih združenj, povojne sabotaže v podjetjih, pisanje lažnih biografij in neutemeljenih priporočil nekdanjim sojetnikom itd.

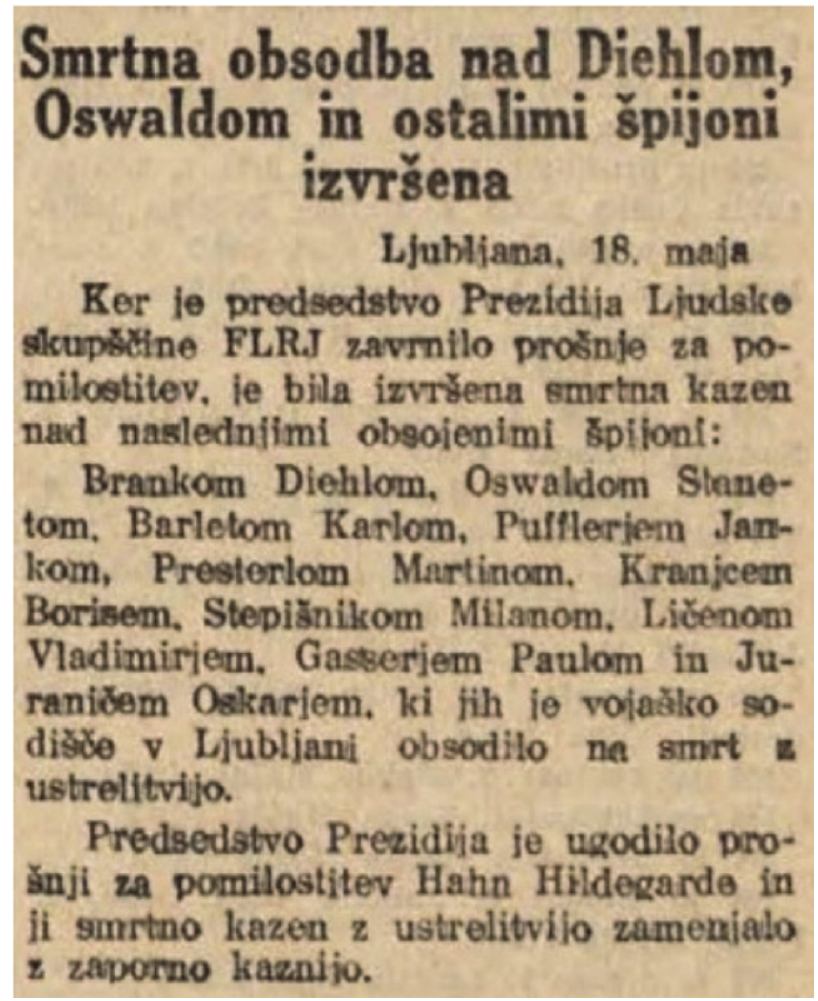

Slika 5: Novica, objavljena v časopisu Ljudska pravica dne 19. maja 1948. Istega dne je podobno kratka novica izšla tudi v Slovenskem poročevalcu, le da je bila datirana s 17. majem. Čeprav v članku ni navedeno, naj bi usmrtitev izvedli 12. maja, o čemer obstaja več pisnih virov. Vendar pa je ta datum usmrtitve vprašljiv, saj Arhiv RS hrani rokopisno Krajnčevo izjavo iz centralnih zaporov Udbe, datirano z 20. majem 1948.

Na prvem in največjem procesu aprila 1948 je bilo obsojenih 14 ljudi, od tega 11 na smrtno kazen (slika 5). Šest obtoženih je bilo kemikov, od tega so jih pet obsodili na smrt. Trije preiskovanci so med zaslišanji umrli, med njimi en kemik. V kasnejših dachauskih procesih so na zaporno kazen obsodili še dva kemika. Kemiki so s svojim strokovnim znanjem, hkrati pa obvladanjem nemškega jezika (znanstvene objave vodilnih slovenskih kemikov v predvojnem času so bile pretežno v nemščini) bili zanesljiv kader za pomoč pri eksperimentalnem delu, v zameno za sodelovanje pa so imeli ugodnejše življenjske razmere $\mathrm{v}$ taborišču, nekateri pa tudi mesečno plačo in možnost izhodov iz taborišča. Ne glede na to pa je po preučitvi očitanih jim dejanj že v 60-tih letih prejšnjega stoletja prevladalo mnenje, da so bili $\mathrm{k}$ sodelovanju $\mathrm{v}$ poskusih prisiljeni in niso imeli možnosti, da bi to delo odklonili. $V$ drugih toč- 
kah obtožnic je bilo po ponovni preučitvi procesov stališče javnega tožilstva, da so bila priznanja izsiljena, sojenja pa nepoštena, zato so bile sodbe razveljavljene. Ponovnih sojenj ni bilo, saj je tožilstvo odstopilo od pregona. Ne glede na to pa so posledice dachauskih procesov zaznamovale ne samo družin obsojenih, pač pa so sojenja negativno vplivala tudi na veteranska združenja španskih borcev in taboriščnikov, nenazadnje pa so posledice bile, vsaj posredno, tudi za kemijsko stroko in njen ugled.

Med obsojenci na smrt na Diehl-Oswaldovem procesu je za biokemijsko stroko še posebej pomemben Boris Krajnc, ki je manj kot dve leti pred aretacijo bil izvoljen v naziv docenta. Pokrival je področje biokemije, kar lahko razumemo kot prvo habilitacijo za to področje na ljubljanski univerzi. S Krajnčevo usmrtitvijo je tehniška fakulteta ostala brez edinega biokemika, predavanja iz biokemije pa je prevzel Dušan Stucin z Medicinske fakultete. Šele v začetku 60-tih let se je biokemija na takratni Fakulteti za naravoslovje in tehnologijo ponovno vzpostavila, medtem pa so druge kemijske discipline skoraj 15 let napredovale sorazmerno neovirano, tako kadrovsko kot raziskovalno.

\section{Zahvala}

Osnovni podatki o dachauskih zapornikih so iz Arolsenskega arhiva (The Arolsen Archives - International Center on Nazi Persecution). Tatjani Peterlin-Neumeier se zahvaljujem predvsem za prepis tistega dela pogovora z Mirkom Dermeljem iz leta 2012, v katerem se spominja Borisa Krajnca, ter za nekatere informacije, povezane $\mathrm{z}$ Maksom Samcem in Mirkom Dermeljem. Za nekatera dodatna pojasnila glede dela Rascherjeve skupine in osebnosti njegovih sodelavcev se zahvaljujem Hubertu Rehmu. Zdaj že pokojnemu Pavlu Ledineku se zahvaljujem za nekatere podatke o Milanu Stepišniku in njegovi družini, Katarini Stepišnik pa predvsem za dostop do dachauskega laboratorijskega dnevnika Milana Stepišnika, izvlečkov iz zaslišanj Milana Stepišnika in nekaterih pisem iz arhiva družine Stepišnik. Antonu Piberniku se zahvaljujem za dopolnitev podatkov o pred- in medvojnem delovanju njegovega očeta Mirka Pibernika, Primožu Sarku pa za nekatere informacije o njegovem očetu Mitji Sarku. Arhivska služba UL mi je posredovala kopijo rokopisa Borisa Krajnca in Branka Diehla, podatek o seji senata UL decembra 1945 ter kopije korespondence o imenovanju v docentski naziv. Fakultetna knjižnica mi je omogočila vpogled v diplomski nalogi Bojana Držaja in Jelke Ružič. Obema se zahvaljujem za pomoč. Za dostop do arhivskega gradiva, povezanega $\mathrm{z}$ dachauskimi procesi, se zahvaljujem Arhivu Republike Slovenije, še posebej Tadeju Cankarju. Hvala tudi Saši Florjančič iz Kovaškega muzeja Kropa za podatke o povezavi med družinama Ažman in Žukov. Prav tako se zahvaljujem Nataliji Štular iz Slovenskega planinskega muzeja, ki mi je posredovala podatke, povezane $\mathrm{z}$ Ivanko Krajnc, in Ani Logar za nekatere podatke o zapuščini Bo- risa Krajnca, ki jo je hranila Ivanka Krajnc. Emiliji Snoj se zahvaljujem za pojasnilo glede pridobitve izjave Antona Debevca o življenju Borisa Krajnca po uradnem dnevu usmrtitve.

\section{Viri}

1. M. Dolinar, Richard Klemen, the first lecturer of enzymology at the University of Ljubljana, Acta Chim. Slov. 2020, 67, S49S61. DOI:10.17344/acsi.2020.6152

2. K. Hess, B. Krajnc, Die Endgruppenbestimmung bei den Stärkekomponenten (X. Mitteil. über Stärke), Berichte der deutschen chemischen Gesellschaft 1940, 73, 976-979.

DOI:10.1002/cber.19400730909

3. K. Hess, H. A. Schulze, B. Kranjc, Über höchstmethylierte Stärke und die Frage ihrer Spaltzucker (XI. Mitteil. über Stärke), Berichte der deutschen chemischen Gesellschaft 1940, 73, 1067-1076. DOI:10.1002/cber.19400731008

4. V. Zimmermann, Eine Deutsche hat mich beim Kapitän denunziert, Südostschweiz, 5. 4. 2011. Dostopno na https:// www.suedostschweiz.ch/zeitung/eine-deutsche-hat-mich-beim-kapitan-denunziert (datum dostopa 4.1.2021).

5. T. Škarja, Odličen zgled in vzornik. Mirko Dermelj - stoletnik. Planinski vestnik 2104, 11, 26-27.

6. J. Petrovec, Mirko Dermelj - Neobvezno v nedeljo (intervju). 19. 10. 2014, dostopno na https://4d.rtvslo.si/arhiv/neobvezno-v-nedeljo/174300165 (datum dostopa 4. 1. 2021).

7. M. Walker, O. Hahn, Verantwortung und Verdrängung, Ergebnisse, 10. zvezek raziskovalnega programa "Geschichte der Kaiser-Wilhelm-Gesellschaft im Nationalsozialismus«, Berlin: Max-Planck-Gesellschaft, 2003.

8. Spremembe v vojaški službi. Novine Slovenske krajine 1940, 27 (38), str. 2. (datum objave 22.9. 1940)

9. D. Siter, Kapitulacija jugoslovanske kraljeve vojske. Objavljeno 17. 4.2017 na http://zgodovina.si/kapitulacije-jugoslovanske-kraljeve-vojske/ (datum ogleda 4.1.2021).

10. H. Kamberović, Nasilje kao sudbina? Sarajevo na razmeđu carstava i država u 20. stoljeću. V: Između rata i mira - Sarajevo u prelomnim godinama 20. stoljeća. Sarajevo: Udruženje za modernu historiju, 2020, str. 9-28.

11. I. Janžekovič, R. Knez, I. Ros, F. Strmole, S. Šifrer, Analiza dachauskega procesa in obdelava posameznikov, obsojenih v tem procesu. V: Dachauski procesi (ur. M. Ivanič). Ljubljana: ČZDO Komunist, 1990, str. 382-503.

12. M. Pukrop, SS-Mediziner zwischen Lagerdienst und Fronteinsatz. Die personelle Besetzung der Medizinischen Abteilung im Konzentrationslager Sachsenhausen 1936 - 1945. Doktorska disertacija. Hannover: Gottfried Wilhelm Leibniz Universität Hannover, 2015, str . 36 in 375.

13. Znanstveno djelo Bože Težaka, Božo Težak (1907-2017): vizionar informacijskih i komunikacijskih znanosti 21. stoljeća / Visionary of information and communication science of the 21st century, Informatol. 2017, 50, 1-13.

14. Dokumenti o razveljavitvi sodbe Fakina in Mrzela. V: Da- 
chauski procesi (ur. M. Ivanič). Ljubljana: ČZDO Komunist, 1990, str. 766-827.

15. M. Cacan, Tibor Škerlak - In memoriam. Glasnik hemičara $i$ tehnologa Bosne i Hercegovine 2012, 38, 69-71.

16. B. Ziherl, Promemorija. V: Dachauski procesi (ur. M. Ivanič). Ljubljana: ČZDO Komunist, 1990, str. 25-32.

17. A. Gabrič, Odpuščanje profesorjev Univerze v Ljubljani iz službe zaradi politično-ideoloških vzrokov, Univerza v Ljubljani, Objave 2000, 6, 12-32.

18. S. Florjančič, Justin in Rika Ažman iz Krope. Življenje pred in med drugo svetovno vojno. Vigenjc 2015, 15, 7-51.

19. E. Snoj, Dachauski procesi kot primer nemoči posameznika na montiranem procesu totalitarnega sistema. Diplomsko delo. Ljubljana: Univerza v Ljubljani, Filozofska fakulteta, Oddelek za sociologijo, 2001.

20. H. Halbrainer, Josef Martin Presterl. Ein Grazer Spanienkämpfer und Verleger als Opfer der Schauprozesse 1948. V: Alfred Klahr Gesellschaft - Mitteilungen, 2016, 23(3), 9-13.

21. R. L. Berger, Nazi Science - The Dachau Hypothermia Experiments. N. Engl. J. Med. 1990, 322, 1435-1440.

DOI:10.1056/NEJM199005173222006

22. A. Riedle, Medizinische Humanexperimente im KZ Dachau am Beispiel der Versuche von Dr. Sigmund Rascher und Prof. Dr. Claus Schilling. Betrifft Widerstand 2015, 129, 12-23.

23. F. Schmaltz, Kampfstoff-Forschung im Nationalsozialismus: Zur Kooperation von Kaiser-Wilhelm-Instituten, Militär und Industrie. Göttingen: Wallstein Verlag, 2005, str. 174-177.

24. M. H. Kater, Das „Ahnenerbe“ der SS 1935-1945, Ein Beitrag zur Kulturpolitik des Dritten Reiches, 4. izdaja. München: R. Oldenbourg Verlag, 2006, str. 231-264

DOI:10.1524/9783486594683

25. S. Bär, Der Untergang des Hauses Rascher. Das bizarre Leben des Dachauer KZ-Artzes, 5. izdaja. Rottweil: Siegfried Bär, samozaložba, 2020.

26. National Archives Catalog, Case Number 000-50-2, Vol 1: Freezing experiments carried out by Dr Rasher..., 1942-1944; Category: Medical Experiments and Reports, Fold3, File \#232070885, str. 18. Dostopno na https://catalog.archives. gov/id/40947627 (datum ogleda 2.6.2021).

27. HLS Nuremberg Trials Project (zapisnik sojenja na Nürnberškem procesu 2. 1. 1947), str. 973. Dostopno na http:// nuremberg.law.harvard.edu/transcripts/1-transcript-for-nmt-1-medical-case?seq=993 (datum ogleda 2. 6. 2021)

28. G. Römer, Schlachters. V: Wolfgang Benz, Barbara Distel (ur.): Der Ort des Terrors. Geschichte der nationalsozialistischen Konzentrationslager. Band 2: Frühe Lager, Dachau, Emslandlager. München: C.H. Beck, 2005, 481-482.

29. G. Sack, Über die Hämostyptische Wirkung der Pektine, Insbesondere bei Hämophilie. Klinische Wochenschrift, 1935, 14, 1536-1538. DOI:10.1007/BF01780472

30. E. Gohrbandt, Die Einwirkung der Pektine auf die Blutgerinnung, Deutsche medizinische Wochenschrift, 2. 10. 1936, 1625-1626. DOI:10.1055/s-0028-1141334

31. World Trade News on Chemicals and Allied Products, United States Bureau of Foreign and Domestic Commerce 11(52), 25. 12. 1937, str. 863.
32. A. Knoll, Lochau. V: Wolfgang Benz, Barbara Distel (ur.): Der Ort des Terrors. Geschichte der nationalsozialistischen Konzentrationslager. Band 2: Frühe Lager, Dachau, Emslandlager. München: C.H. Beck, 2005, 385-387.

33. B. Krivokapić, Dahauski procesi, Beograd: Prosveta, 1986.

34. Digitalni arhiv ITS, Bad Arolsen, št. dokumenta 4.2/82231970 (1943).

35. Pseudo-medizinsiche Versuche in KL Dachau. Erprobung des Blutstillmittels »Polygal 10«. Digitalni arhiv ITS, Bad Arolsen, št. dokumentov 4.2 / 82231949- 82231953 (1969).

36. V. Kopač, F. Žemva, B. Albaneze, Delo jugoslovanskih komunistov v taborišču. V: Dachau, zbornik (ur. L Bukovac). Ljubljana: Založba Borec, 1981, str. 253-289.

37. Pogrebni govor - Rudi Janhuba. Avtor neznan. 1976. Objavila Mestna knjižnica Ljubljana 21. 5. 2016. Dostopno na https:// www.kamra.si/mm-elementi/item/pogrebni-govor-rudi-janhuba.html (datum ogleda 27. 1. 2021).

38. C. Kohl: The Witness House: Nazis and Holocaust Survivors Sharing a Villa during the Nuremberg Trials. New York: Other Press, 2010.

39. HLS Nuremberg Trials Project (zapisnik sojenja na Nürnberškem procesu 21. 3. 1947), str. 2344. Dostopno na http:// nuremberg.law.harvard.edu/transcripts/2-transcript-for-nmt-2-milch-case?seq=2935 (datum ogleda: 2. 6. 2021).

40. J. Reitzenstein, Himmlers Forscher: Wehrwissenschaft und Medizinverbrechen im „Ahnenerbe“ der SS. Paderborn: Verlag Ferdinand Schöningh, 2. izdaja, 2020.

41. V. Kopač, Izjava Vlasta Kopača o preiskovalnem postopku. V: Dachauski procesi (ur. M. Ivanič). Ljubljana: ČZDO Komunist, 1990, str. 347-354.

42. M. Jeraj, O rabi in zlorabi arhivskega gradiva tajnih služb (na primeru pripovedi o Milovanu Ilichu, objavljene v Koroških vojnih zgodbah). Prispevki za novejšo zgodovino 2018, 58(2), 190-205.

43. E. Djogič, Razvoj slovenske atletike od leta 1945 do 1950 . Univerza v Ljubljani, Fakulteta za šport, diplomsko delo, 2007.

44. Arhiv Republike Slovenije, SI AS 1529, škatla 24.

45. M. Horvat, V. Kopač, Vlasto Kopač: "Nič nisem zagrešil in tudi milosti ne bom prosil«, Delo, Sobotna priloga 31. 8. 2013 (dostopno na spletu https://old.delo.si/zgodbe/sobotnapriloga/vlasto-kopac-nic-nisem-zagresil-in-tudi-milosti-ne-bom-prosil.html, datum ogleda 13.11.2020).

46. F. Jauk, Wir haben die Losung von Dachau gelernt. Hundert Monate in Dachau und Gestapohaft. Graz: KPÖ Steiermark, 1988.

47. H. Halbreiner, Franz Jauk. Ein Grazer Widerstandskämpfer als Zeuge der NS-Medizinverbrechen im KZ Dachau. Alfred-Klahr-Gesellschaft Mitteilungen 2016, 16(2), 22-24.

48. M. Samec, Studien über Pflanzenkolloide XXIII.: Lösliche Stärken erhalten durch Einwirkung von Oxydationsmitteln / nach Versuchen von M. Pibernik, Kolloidchemische Beihefte 1929, 28, 155-166. DOI:10.1007/BF02557607

49. M. Pibernik, B. Gregorka, Proste vežbe za I pokrajinski slet u Ljubljani i za međusletske utakmice 1933 = Proste vaje za I. pokrajinski zlet v Ljubljani in za medzletne tekme 1933, Načelništvo Saveza sokola kraljevine Jugoslavije. Ljubljana: Učiteljska tiskarna, 1933. 
50. P. Vodopivec, Prispevek za zgodovino represije na Slovenskem po 2. svetovni vojni, Neobjavljen intervju z Vlastom Kopačem iz leta 1986. Prispevki za novejšo zgodovino LII 2012, 52(2), 274-294.

51. T. Velikonja, Zarja miru in mrak božičnega procesa, Zaveza 19, 1995; dostopno na http://nszaveza.github.io/articles/19zarja-miru-in-mrak-bozicnega-procesa/ (datum ogleda 2.6.2021).

52. I. Žajdela, Da bi bili složni, Reporter 2019, 12(18), 56-57 (datum objave 6. maj 2019). Povzeto po Biltenu Inštituta za narodnostna vprašanja 209 (3.-9. 5. 2019).

53. L. Malec, Ličen, Vladimir. V: Primorski slovenski biografski leksikon. Gorica : Goriška Mohorjeva družba, 1993. 19. snopič. Dostopno na: Primorci.si, spletni biografski leksikon znanih Primork in Primorcev, http://www.primorci.si/osebe/ li\%C4\%8Den-vladimir/903/, zadnja sprememba 6. 3. 2013 (datum dostopa 19. 8. 2020).

54. M. Ivanič, Kronološki prikaz poteka in razveljavitve dachauskih procesov (1946-1986). V: Dachauski procesi (ur. M. Ivanič). Ljubljana: ČZDO Komunist, 1990, str. 33-51.

55. F. Novak, Banovinski institut za raziskovanje in zdravljenje novotvorb, Radiološki glasnik 1938, 3-4, 122-124.

56. L. Šavnik, V. Premru, Ein Beitrag zur cancerogenen Wirkung der Stilbenpräparate. Zeitschrift für Krebsforschung 1941, 51, 337-343. DOI:10.1007/BF01621005

57. L. Šavnik, V. Premru, Experimentelle Ergebnisse über die krebsverursachende Wirkung der Stilbenpräparate. Zeitschrift für Krebsforschung 1942, 52, 83-90.

DOI:10.1007/BF01621318

58. F. Koblar, Premru, Vladimir (1902-1949). Slovenska biografija. Slovenska akademija znanosti in umetnosti, Znanstvenoraziskovalni center SAZU, 2013. Dostopno na http://www. slovenska-biografija.si/oseba/sbi460489/\#slovenski-biografski-leksikon (datum ogleda 29. junij 2020). Izvirna objava v: Slovenski biografski leksikon: 8. zv., ur. F. K. Lukman, Ljubljana: Slovenska akademija znanosti in umetnosti, 1952.

59. N. Troha, Poročilo notranjega ministra LRS Borisa Kraigherja na seji Politbiroja Centralnega komiteja Komunistične partije Slovenije, 9. marec 1950 (komentirana objava rokopisnih beležk). Prispevki za novejšo zgodovino, 2018, 58 (3), 151-170. Dostopno tudi na https://ojs.inz.si/pnz/article/view/307/1270 (datum ogleda 3. 6. 2021).
60. Vmesno poročilo o povojnih množičnih pobojih. 16. seja, 9. 6. 1994 - Dušan Bravničar, Franc Konobelj. Poročevalec Državnega zbora Republike Slovenije 1996, 42, 38-39.

61. Z. Čepič, Od Inštituta za zgodovino delavskega gibanja do Inštituta za novejšo zgodovino. V: Zgodovinopisje v zrcalu zgodovine: 50 let Inštituta za novejšo zgodovino, ur. A. Gabrič. Ljubljana: Inštitut za novejšo zgodovino, str. 49-126, 2009.

62. T. Kukovica, Gledanje med vrsticami, Sladka lažnost demokratičnega bivanja. Gorenjski glas, 9.3.1991, str. 12.

63. M. Kocjan-Barle, Pogovor z Mitjem Sarkom, Nova revija 1994, 143, 58-87.

64. M. Jevnikar, Torkar Igor. V: Primorski Slovenski biografski leksikon, 16. snopič, ur. M. Jevnikar, Gorica: Goriška Mohorjeva družba, 1990, str. 32-34.

65. F. Derganc, Kakor tujca, Zgodba iz življenja. Dolenjski list 1991, 41 (19), 8. (datum objave 10. 5. 1991)

66. F. Pivec, Osamosvajanje študentske skupnosti. Slovensko študentsko gibanje v šestdesetih letih. V: Slovenija - Jugoslavija, krize in reforme 1968/1988 (ur. Zdenko Čepič). Ljulbjana: Inštitut za novejšo zgodovino, 2010, str. 295-304.

67. R. Ivelja, Usoda na smrt obsojenih še vedno ovita v skrivnost. Dnevnik, 26. 4. 2003. Dostopno na https://www.dnevnik. si/49206 (datum ogleda 3. 6. 2021).

68. R. Kocjančič, Kot so bili montirani dachauski procesi, tako so bile montirane tudi rehabilitacije obsojencev (2.), Reporter, 1. 6. 2015. Dostopno na https://reporter.si/clanek/ kolumnisti/rudi-kocjancic-kot-so-bili-montirani-dachauski-procesi-tako-so-bile-montirane-tudi-rehabilitacije-obsojencev-2-480347 (datum ogleda 3. 6. 2021).

69. T. Wraber, Poročilo o delu 1. komisije za rehabilitacijo univerzitetnih učiteljev, Univerza v Ljubljani, Objave 6/2000, 11.

70. P. Weindling, A. von Villiez, A. Loewenau, N. Farron, The victims of unethical human experiments and coerced research under National Socialism. Endeavour 2016, 40(1), 1-6. DOI:10.1016/j.endeavour.2015.10.005

71. P. Pahor, Kraigherjeva živela vsak na svojem koncu. Dnevnik, 29. 10. 2011. Dostopno na https://www.dnevnik. si/1042484192 (datum ogleda 3. 6. 2021).

72. P. Weindling: Victims and Survivors of Nazi Human Experiments: Science and Suffering in the Holocaust. London: Bloomsbury Academic, 2015.

\section{Abstract}

At the University of Ljubljana, Boris Krajnc was the first habilitated teacher to cover the subject of biochemistry: he was appointed on January 5, 1946. However, Krajnc's life ended abruptly. He was arrested on October 17, 1947 and sentenced to death on April 26, 1948 in the mounted Dachau Trial in Ljubljana. He was reportedly shot on May 12, 1948, at the age of 34. The life story of Boris Krajnc is closely linked to the work of several Slovenian chemists who were selected as prisoners at Dachau Concentration Camp to provide technical assistance in human experiments or in the clinical laboratory of the camp hospital. In the post-war period Dachau Trials in Ljubljana, a total of 8 chemists were convicted, 5 of whom were sentenced to death and executed by firing squad. In later evaluations of Dachau Trials it turned out that the charges were constructed and the confessions were obtained by cruel interrogation methods, therefore all judgements were annulled. After the emigration of the enzymologist Richard Klemen (1942) and the expulsion of Maks Samec and Marta Blinc from the university (1945), Boris Krajnc was to supervise biochemistry at the Technical Faculty. After his death, the lecturer of biochemistry was Dušan Stucin from the Medical Faculty. Later, biochemistry was absent from the chemistry curriculum for several years. 